\title{
Article \\ Improving Audit Reports: A Consensus between Auditors and Users
}

\author{
Estibaliz Goicoechea *(D), Fernando Gómez-Bezares (D) and José Vicente Ugarte $\mathbb{D}$ \\ Department of Finance and Economics, University of Deusto, Avenida de las Universidades, 24, \\ 48007 Bilbao, Spain; f.gomez-bezares@deusto.es (F.G.-B.); jvugarte@deusto.es (J.V.U.) \\ * Correspondence: estibaliz.goicoechea@deusto.es; Tel.: +34-944-139-000
}

check for updates

Citation: Goicoechea, Estibaliz, Fernando Gómez-Bezares, and José Vicente Ugarte. 2021. Improving Audit Reports: A Consensus between Auditors and Users. International Journal of Financial Studies 9: 25. https://doi.org/10.3390/ijfs9020025

Academic Editor: Sakthi Mahenthiran

Received: 1 March 2021

Accepted: 26 April 2021

Published: 29 April 2021

Publisher's Note: MDPI stays neutral with regard to jurisdictional claims in published maps and institutional affiliations.

Copyright: (c) 2021 by the authors. Licensee MDPI, Basel, Switzerland. This article is an open access article distributed under the terms and conditions of the Creative Commons Attribution (CC BY) license (https:/ / creativecommons.org/licenses/by/ $4.0 /)$.
Abstract: Audit reports represent the only information stakeholders have about conducted audits and they are a key instrument used in economic and financial decisions. Improving audit reports should be a priority of regulators and auditors. The authors solicited perceptions from 212 experienced auditors and financial report users about the value of audit reports and ways to improve their format and content. An analysis of the responses suggests that adding information on audits (such as auditor's responsibility about fraud) and on annual accounts and client's information systems, without significant changes in the format, would improve the decision usefulness of audit reports. The growing sophistication of markets and reporting standards requires new information in audit reports, such as auditors' conclusions about management's estimates in annual accounts. The study is useful to regulators, auditors' corporations, academics, and users and contributes to the current audit literature by providing evidence on consensus between auditors and users with regard to the format and content of audit reports.

Keywords: audit report; information value for decision making; consensus between auditors and users

\section{Introduction}

Recent research on audit reports (Bédard et al. 2016; Chen et al. 2020; Coram and Wang 2020; MARC 2011; Mock et al. 2013), as well as recent regulatory proposals and initiatives by the main international organizations in the audit field to improve current audit reports (European Parliament 2014a; IAASB 2015a, 2015b), show that the old and long debate about audit reports is far from settled.

The audit report is one of the main instruments used by stakeholders when making economic and financial decisions. Regulators, auditing standard setters, academics, and international organizations are attempting to improve the information communicated by audit reports to stakeholders and to promote audit quality and transparency through the format and content of these reports (Bédard et al. 2016; European Parliament 2014a; IOSCO 2009; Vanstraelen et al. 2012). Auditors instill confidence in the markets when they assure financial information but they primarily communicate with stakeholders through 'carefully worded' audit reports (Gray et al. 2011; Gutierrez et al. 2018). Therefore, it is very important that audit reports contain information stakeholders need to make their decisions and that these reports enhance the relevance and value of audits. In addition, regulators and audit standard setters must ensure that expectation, information and communication gaps do not increase in the future (Humphrey et al. 1993; IAASB 2011a; IOSCO 2009; Mock et al. 2013; Porter 1993). For efforts to improve audit reports to be successful, agreements between auditors and financial report users regarding their content and format are imperative (Vanstraelen et al. 2012). Previous changes to audit report did not narrow the expectation gap (Mock et al. 2013). Only through consensus can we advance in this way.

Our study seeks to contribute to the audit report debate and to find a consensus between financial report users and auditors with regard to the format and content of audit 
reports in order to improve their value for decision making. Our study responds to calls from academia for more research on the content and the format of audit reports to support decision making (Bédard et al. 2016; Church et al. 2008; MARC 2011; Mock et al. 2013; Turner et al. 2010). Gray et al. (2011) pointed out that an important issue lacking attention in the audit report research is 'a better understanding of what users want, instead of what the profession (or regulators) believes is wanted' (p. 663). Our study, based on a survey, complements and extends previous studies on this topic based mainly on interviews (MARC 2011; Vanstraelen et al. 2012).

We solicited the perceptions of auditors and financial report users (henceforth 'users') in Spain through an anonymous online survey to address the following research questions (RQ):

RQ1: What decision-making value do stakeholders attribute to audit reports?

RQ2: What content should audit reports contain in order to enhance their value for decision making?

RQ3: What format should audit reports have in order to enhance their value for decision making?

The three research questions are supported by an extent literature (e.g., Bédard et al. 2016; Köhler et al. 2020). Our literature review will enrich and support the research questions. RQ1 is covered in Section 2.1, RQ2 and RQ3 are covered in Section 2.2 of our literature review.

We have conducted a survey with users and auditors in Spain in April 2016. The survey referred to the audit report in force in Spain at that point of time (ICAC 2013). Audit reports in Spain were subsequently modified by Norma Internacional de Auditoría (NIA-ES) 700 (ICAC 2016a) and NIA-ES 701 (ICAC 2016b), effective for audits of financial statements for periods beginning on or after 17 June 2016.

The aim of our work is, firstly, to determine the value attributed by stakeholders to audit reports, as well as users' and auditors' preferences regarding content and format of audit reports in the summer of 2016. Secondly and fundamentally, we aim to compare these preferences with the changes introduced by the new legislation to detect unmet necessities. Our ultimate purpose is to propose an alternative audit reporting model to the current one, as per International Standard on Auditing (ISA) 700 (IAASB 2015a), finding a consensus between auditors and users.

With this goal in mind, we present a descriptive and inferential analysis of the perceptions of 109 users and 103 auditors. Overall, our respondents considered that stakeholders attribute high decision-making value to audit reports. Nevertheless, they thought that value could be enhanced by adding information on audits carried out and information on annual accounts and the client's information systems. With regard to report format, respondents preferred formats similar to the current ones.

Our study makes several contributions. It provides evidence on the perceptions of auditors and financial report users and their consensus regarding audit reports, the value of these reports and ways to improve them. This information could be valuable for auditing standard setters because it describes the consensual necessities of both groups regarding audit reports. Our study compares these necessities with the novelties introduced by the legislation and proposes an alternative audit reporting model. Recent changes to audit report were implemented without empirical evidence on the desirability of these changes (Coram and Wang 2020). Future modifications to audit reports should seek an agreement between auditors and users in order to guarantee that changes are successful (Vanstraelen et al. 2012). In addition, our findings may be useful for audit practice because they may be an important step in reducing the expectation, information and communication gaps in audit reports and enhancing transparency regarding the quality of audit practice. Recent financial scandals have been accompanied by a loss of reputation for audit activity. Finally, we contribute to the literature on audit and audit reports. We provide academia with evidence about alternatives to improve audit reports in order to satisfy the demands of users and the possibilities of auditors. In addition, we demonstrate that achieving a level 
of consensus between auditors and users is possible. Our study illustrates certain areas that are the most likely to benefit from future research.

The remainder of the paper is structured as follows. Section 2 provides the background and basis for this study. Section 3 describes the methodology, including the participants and survey development. Section 4 presents and discusses the results. Section 5 states our proposed audit report. We conclude with a summary of our findings, the study's limitations, and suggestions for future research.

\section{Background and Literature Review}

In this section, the extant literature on audit report is reviewed under two broad headings: the first is the value of audit reports, and the second is the proposals of content and format modifications to enhance the value of audit reports.

\subsection{The Value of Audit Reports for Stakeholders}

Despite the abundant and detailed regulation related to audit activity in general and audit reports in particular, the debate about these reports' content, format and value is ongoing (Bédard et al. 2016; Chen et al. 2020; Coram and Wang 2020; Mock et al. 2013; IOSCO 2009), as evidenced by recent regulatory changes and literature on the topic.

Auditing standard setters have approved significant recent changes in audit reports. The International Auditing and Assurance Standards Board (IAASB) (2015a, 2015b) issued ISA 700 and ISA 701, the UK and Ireland Financial Reporting Council (FRC 2013) has issued ISA 700, and the European Union (EU) adopted, in April 2014, Directive 2014/56/EU, which introduced significant changes to audit reports, among other things (Horton et al. 2018). These steps were demanded by regulators and others [International Organization of Securities Commissions (IOSCO) Technical Committee (IOSCO 2009); EC (2010); PCAOB (2011)] after questioning the value of audit reports in the aftermath of the 2008 financial crisis.

In addition, there is abundant recent literature on this subject. Two important papers have reviewed the literature on audit reports in recent years. Mock et al. (2013), building on the work of Church et al. (2008), analysed work on audit reports up to 2011. Bédard et al. (2016) provided a synthesis of audit report research published from 2007 to 2015.

The main issue in the international debate about the format and content of audit reports is whether current models are adequate for stakeholders to make decisions and correctly inform users about the quality of audits (Bédard et al. 2016; IOSCO 2009; Vanstraelen et al. 2012).

Many studies have analysed the impact of audit opinion types on different stakeholders' perceptions and decisions. Some authors argue that the type of audit opinion affects investment analysts' investment decisions (Duréndez Gómez-Guillamón 2003; Firth 1980), loan officers' lending decisions (Duréndez Gómez-Guillamón 2003; Firth 1980) and investors' decisions (Chen and Church 1996; Chen et al. 2020; Ghicas et al. 2008; Kausar and Lennox 2017; Köhler et al. 2020; Ianniello and Galloppo 2015; O’Reilly 2010). However, other studies indicate that although audit reports contain useful information, other sources of information are consulted by analysts (Ghicas et al. 2008; Vergoossen 1993), by private shareholders (Bartlett and Chandler 1999; Coffee 2019) and by venture capitalists (Wright and Robbie 1996; Manigart et al. 1997) in their decision making.

After reviewing the existing literature on auditors' reporting model prior to 2007, Church et al. (2008) concluded that an audit report 'has symbolic value, but conveys little communicative value' (p. 85). Similarly, Mock et al. (2013) concluded that the cause for the low communicative value may be the 'boilerplate language' (p. 345). Auditor's reports are important to analysts as a signal of financial statements' reliability (Coram et al. 2011), but analysts (Coram et al. 2011) and other users (Turner et al. 2010) pay little attention to the content of audit reports. Other studies found that financial analysts (Coram et al. 2011) and other groups of audit report users (financial directors, bankers, analysts, non-professional investors and auditors themselves) (Gray et al. 2011) do not pay excessive attention to the content of audit reports once they know that the opinion is favorable. Porter et al. (2009) 
showed that $47 \%$ of non-professional investors in the UK and New Zealand rarely read audit reports in their entirety. Muñoz-Izquierdo et al. (2019) reported that users of audit report do not need to read the complete audit report to predict chances of bankruptcy.

Evidence of an expectation gap, defined by Porter (1993) as a difference between the perceived performance of auditors and society's expectations, has been studied all over the world (Epstein and Geiger 1994; Garcia-Benau et al. 1993; Humphrey et al. 1993; Porter 1993; Ruhnke and Schmidt 2014). The argument regarding the existence of such an expectation gap was long used as a reason not to introduce modifications to audit reports but rather to correct unreasonable expectations and users' misperceptions (Epstein and Geiger 1994; Humphrey et al. 1992). However, studies have shown that the need for users' education is not high (Chen et al. 2020; Porter et al. 2009; Vanstraelen et al. 2012) or has to be complemented with changes in audit report content and format (Coram and Wang 2020). The continuing debate on audit reports is probably intensified by the lack of transparency on the quality of audits, the absence of clarity regarding the factors that affect audit opinions (Caso et al. 2003) and the loss of auditors' reputation (due to the financial scandals of recent years) (Coffee 2019; Vanstraelen et al. 2012). Recent studies have focused on the information gap, defined as the difference between users' information needs to make decisions and the information available through financial accounts and audit opinion (Vanstraelen et al. 2012; IOSCO 2009; IAASB 2011a), and the communication gap, 'the difference between what users desire and understand and what is communicated by the assurance provider' (Mock et al. 2013, p. 327). The experimental research suggests that the information gap still persists despite the new disclosures introduced by the latest auditing standards (Bédard et al. 2016). Considering that an audit report is 'the only outcome of the audit process that is observable to investors' (Carcello 2012, p. 22) and that auditors should show the quality of their activity in order to recover their reputation, it is important that academia, auditors and auditing standard setters collaborate to improve audit reports (Gray et al. 2011).

In light of the above, there is still room for improving the decision usefulness of audit reports. The next section examines different proposals from academia, auditing standard setters and audit firms.

\subsection{Efforts to Increase the Value of Audit Reports by Changing Their Content and Form}

There are many proposals from academia, auditing standard setters and even audit firms to improve the value of audit reports by changing their content and format. The purpose is to close the expectation, information and communication gaps (henceforth 'gaps') and to enhance the transparency of audit quality and therefore the credibility of audit activity (Bédard et al. 2016; European Parliament 2014a; IOSCO 2009; Vanstraelen et al. 2012).

The research until the end of 2011 is consistent across countries, research methods and time in recommending the elimination of boilerplate language in audit reports to improve their communicative value (Coram et al. 2011; Gray et al. 2011; Mock et al. 2013; Turner et al. 2010). The move towards longer-form audit reports did not narrow the gaps (Coram et al. 2011; Gray et al. 2011; Mock et al. 2013; Turner et al. 2010), as little information was found in audit reports 'about the specific work undertaken and findings obtained by auditors' (Humphrey et al. 2009, p. 819).

The sophistication and growing complexity of the financial and capital markets have caused changes in accounting policies and company reports. The information on the use of fair value (McDonough et al. 2020), on estimates and on the models used to calculate certain values has forced audit activity and audit reports to evolve to meet the expectations of stakeholders regarding the assurance of these notes (Deloitte 2015; IAASB 2011b; Mao and Yu 2015).

The growing interest in non-financial information (Eccles et al. 2012; Kolk and Van Tulder 2010; KPMG 2017; Manes-Rossi et al. 2018) and the changes in corporate reporting models, such as integrated reporting (IIRC 2013), will demand a change in audit activity 
and therefore in audit reports (Cheng et al. 2014; De Villiers et al. 2014; Eccles et al. 2012; Gómez-Bezares and Goicoechea 2013; Goicoechea et al. 2019; IIRC 2014; Rossi and Tarquinio 2017).

The 'wish list' of items to include in audit reports to enhance their value is extensive (Carcello 2012). The IAASB (2011a) Consultation Paper identified two broad categories of information wanted by users: information about the audited entity and its annual accounts and information about the audit performed. Mock et al. (2013) concluded in their literature review that users want more information about financial statements, audits and auditors. Based on an extensive literature review, Maastricht Accounting Auditing and Information Management Research Center (MARC) (2011) identified five categories of information that could be included in audit reports: information that clarifies the scope of the audit and the language in audit reports to help users better understand the purpose and limitations of a financial statement audit (Church et al. 2008; CFA Institute 2010; Hatherly et al. 1991; Gray et al. 2011; IAASB 2011a, 2011b; Manson and Zaman 2001; Porter et al. 2009; Turner et al. 2010); information on the audit team, specialists' involvement in the audit engagement and engagement statistics to help users assess and understand the quality of the audit engagement (Balsam et al. 2003; Carey and Simnett 2006; CFA Institute 2010; IAASB 2011a, 2011b; Johnstone and Bédard 2001; Knechel et al. 2007; O’Keefe et al. 1994; Reynolds and Francis 2001); information on the audit process to help users appreciate the work done by the auditor and understand the auditor's findings and conclusions (Church et al. 2008; CFA Institute 2010; Knechel et al. 2007; Porter et al. 2009); further information on the results of the auditor's evaluation of the financial statements to help users understand what the auditor's conclusions are based on (Church et al. 2008; CFA Institute 2010, 2011; EC 2010; Gray et al. 2011; IAASB 2011a; IOSCO 2009; Porter et al. 2009; Turner et al. 2010); and disclosures beyond the current scope of the financial statement audit (Coffee 2019), as non-financial information (De Villiers et al. 2014; EC 2010; Eccles et al. 2012; IAASB 2011a; Porter et al. 2009; Simnett and Huggins 2015; Turner et al. 2010).

With regard to the format of audit reports, MARC (2011) distinguished the following different options: maintaining the current audit report format, since many prior studies indicate that audit reports have information value for users (Church et al. 2008; Gaeremynck and Willekens 2003); using a one-sentence audit report about the fairness or quality of audited financial statements, as report users are more interested in whether an audit report is unqualified than in the specific terminology used (Church et al. 2008; McEnroe and Martens 2001); using a one-sentence audit report containing a score (for example between 0 and 10) on the fairness or quality of financial statements (EC 2010; Gray et al. 2011); using a free-form long audit report, tailored to each audit and each audited entity (Church et al. 2008; Turner et al. 2010); and supplementing audit reports with expanded use of emphasis of matters paragraphs and/or with a statement of audit approach as a justification of the auditor's assessment (Gray et al. 2011; Hatherly et al. 1991; IAASB 2011a; Turner et al. 2010).

Recent changes have been approved by auditing standard setters and regulators in the audit report. We focus our attention on Europe, but there are other international initiatives related to the audit report. For example, the PCAOB (2017) has proposed new standards. Although there are coincidences with the IAASB initiatives, we do not attempt to synthesize research related to the other initiatives.

France has required, since 2003, a 'justification of assessment' in audit reports. In the justification, auditors focus on items important to understand the financial statements, their assessments, the procedures performed, and a conclusion. The effects of such disclosures are mixed, as they have not delivered a significant variety of information to users (Bédard and Gonthier-Besacier 2013). Since the fiscal year beginning on 1 October 2012, all companies with a premium listing on the London Stock Exchange were required to follow the expanded model of audit report. Recent research showed little incremental information to investors provided by this audit report (Gutierrez et al. 2018).

Directive 2014/56/EU of the European Parliament and of the Council, of 16 April 2014 (European Parliament 2014a), and Regulation (EU) No 537/2014 of the European 
Parliament and of the Council, of 16 April 2014 (European Parliament 2014b), arose from the need to recover the confidence of the markets in the audited financial information, especially of public-interest entities, and to reinforce the quality of the audits, strengthening the independence of auditor. There was also an interest in increasing the level of convergence with respect to the auditing standards on the basis of which the statutory audits are carried out in the EU. Directive requires, among other things, the audit report to include a description of the most significant assessed risks of material misstatement, a summary of the auditor's response to those risks, and key observations arising with respect to those risks. It also requires the audit report to be signed by the audit engagement partner.

The IAASB issued new audit reporting standards in January 2015, ISA 700 (Revised) 'Forming an Opinion and Reporting on Financial Statements' and ISA 701 'Communicating Key Audit Matters (KAMs) in the Independent Auditor's Report' (IAASB 2015a, 2015b), effective for audits of financial statements for periods ending on or after 15 December 2016. The changes in audit report proposed by ISA 700 aimed to 'increase the value of auditor reporting by making the information provided in the auditor's report more relevant to users' (IAASB 2015a, p. 4).

ISA 700 requires, among other things, the audit report to begin with the auditor's Opinion and the Basis for the opinion. The fact that the opinion is right at the beginning of the audit report emphasizes the importance of the opinion and makes it easier for stakeholders to focus on it (KPMG 2014). Nevertheless, we are of the opinion that it can increase the risk, already described in the literature (Mock et al. 2013), that the rest of the audit report is not read and users just check whether it is qualified or not. With the exception of the Opinion and Basis for the Opinion sections, ISA 700 does not prescribe the order of the rest of elements of the audit report, but requires the use of specific headings: Key Audit Matters, Responsibility of Management for the Financial Statements, Auditor's Responsibilities for the Audit of the Financial Statements (located within the body of the audit report, in an appendix or by a reference to a website) and Other Reporting Responsibilities (if applicable).

The Opinion and the Basis for the opinion are generally followed by the description of the KAMs, in accordance with ISA 701. KAMs are matters that, in the auditor's professional judgement, were of most significance in the audit of the financial statement on the current period. They are selected from matters communicated with those charged with governance (IAASB 2015b). Simnett and Huggins (2014) found that, overall, there was a high level of support from stakeholders to the changes to the audit report proposed by the IAASB (2012). Regarding the KAMs, or the PCAOB critical audit matters (CAMs), they may lead to an improvement of financial reporting quality (Gold et al. 2020; In et al. 2020). However, it is not fully determined by academia, if they close the information gap, or even if they significantly affect investors' reactions, although they give users some of the information demanded (Brasel et al. 2016; Christensen et al. 2014; Gutierrez et al. 2018; Moroney et al. 2020; Velte and Issa 2019). Empirical studies suggest that the KAM section has little communicative value for bank directors (Boolaky and Quick 2016) or investors (Bédard et al. 2014), unless they are professional ones (Köhler et al. 2020). Nevertheless, KAMS may also have some unintended consequences, such as less attention devoted to the remaining parts of the financial statements (Sirois et al. 2018), delays in audit reports, higher audit fees (Velte and Issa 2019) or even an increase in the expectation gap (Coram and Wang 2020).

Directive 2014/56/EU, ISA 700 and ISA 701 were transposed into the Spanish national legislation by Audit Law 22/2015, of 20 July 2015 (Spanish Parliament 2015), NIA-ES 700 (ICAC 2016a) and NIA-ES 701 (ICAC 2016b), respectively.

Audit firms, especially Big 4 (Deloitte, EY, PwC and KPMG), were well aware of the limitations of audit reports before the last regulatory changes. PwC (2014) stated that the audit report did no longer meet the expectations of transparency, as it provided no insights into the process leading up to an unqualified audit opinion. Therefore, audit firms proposed 'plain speaking' (PwC 2014, p. 3), going away 'from the old, binary model of 
either a 'clean' of 'modified' audit opinion' (KPMG 2014, p. 8) and even going further than the IAASB (2012) proposals by informing in the audit report about materiality and group audit scoping (PwC 2014).

From the enumeration of the additional information required by ISA 700 and ISA 701, we infer that regulators have tried to solve some of the problems detected by literature by incorporating more information to the audit report. Nevertheless, there is no empirical evidence that the latest changes were desirable (Coram and Wang 2020), and there are still many unmet demands. To be successful with new audit reports' proposals, we are of the opinion, following Vanstraelen et al. (2012), that it would be necessary to find a consensus between the demands of the users and the possibilities of the auditors.

With this goal in mind, we conducted a survey of auditors and financial report users. We asked them about their perceptions of the value for decision making of the audit report. We also asked them about the format and content audit report should have in order to enhance its value. The next section describes our methodology.

\section{Methodology}

To address our research questions and propose an alternative audit report model, we solicited auditors' and users' perceptions through an anonymous online survey. We distributed the survey to 126 users and 118 auditors in Spain. The study used the same representative sample as Goicoechea et al. (2019), where its elaboration and validity are explained. In total, 109 users and 103 auditors completed the survey, which represents response rates of $87 \%$ and $88 \%$, respectively; these rates lend high validity to the results. Table 1 provides the demographics for the sample of 212 participants.

Table 1. Demographics.

\begin{tabular}{ccccc}
\hline \multirow{2}{*}{ Demographic Variables } & Full Sample & Users & Auditors \\
\hline \multirow{2}{*}{ Gender } & & $100.0 \%$ & $51.4 \%$ & $48.6 \%$ \\
& Male & $64.2 \%$ & $64.2 \%$ & $64.1 \%$ \\
\multirow{2}{*}{ Education level } & Female & $35.8 \%$ & $35.8 \%$ & $35.9 \%$ \\
& Bachelor's degree & $64.6 \%$ & $70.7 \%$ & $58.2 \%$ \\
& Master's degree & $31.6 \%$ & $22.9 \%$ & $40.8 \%$ \\
Years of professional & PhD & $3.8 \%$ & $6.4 \%$ & $1.0 \%$ \\
experience & Under 12 & $30.2 \%$ & $20.2 \%$ & $40.8 \%$ \\
\hline \multirow{2}{*}{ Users' professional } & 12 and over & $69.8 \%$ & $79.8 \%$ & $59.2 \%$ \\
function & CFO & $45.9 \%$ & $45.9 \%$ & - \\
\hline \multirow{2}{*}{ Audit firm size } & CEO & $14.7 \%$ & $14.7 \%$ & - \\
& Other ${ }^{\text {a }}$ & $39.4 \%$ & $39.4 \%$ & - \\
\hline \multirow{2}{*}{ Auditors' rank } & Big 4 & $89.3 \%$ & - & $89.3 \%$ \\
& Non-Big 4 & $10.7 \%$ & - & $10.7 \%$ \\
\hline
\end{tabular}

Notes: ${ }^{\text {a }}$ The areas were mainly consultant $(8.3 \%)$, financial analyst $(5.5 \%)$, university lecturer (5.5\%), internal auditor $(4.6 \%)$, corporate banker $(4.6 \%)$, tax adviser $(3.7 \%)$, non-financial department manager $(2.8 \%)$, and other $(4.6 \%)$.

In total, $36 \%$ of our participants were female, and $64 \%$ were male. Regarding education level, $65 \%$ had a bachelor's degree. Approximately $70 \%$ of our respondents had 12 years or more of professional experience, and 30\% had less than 12 years of experience. Users were mainly chief financial officers (CFOs, 46\%), 15\% were chief executive officers (CEOs), and $39 \%$ worked in other areas (Coram and Wang 2020). The majority of auditors (89\%), on the other hand, belonged to the Big 4 . In terms of rank in the audit firm, 35\% were partners, $44 \%$ were managers, and $21 \%$ were seniors. This led to a very adequate sample for the objectives of our research. The survey was prepared ad-hoc for our investigation. 
We used the Chi-square test to measure the dependence between being a user or auditor and the following demographics: gender ( $p$-value $>0.05)$, education level $(p-$ value $<0.05)$ and years of professional experience $(p$-value $<0.05)$. The higher percentage of auditors with a master's degree in comparison with users is explained by the fact that the Big 4 in Spain offer junior-level auditors master's degrees during their first years of professional experience. On the other hand, the pyramidal structure of audit firms explains the higher percentage of auditors with fewer than 12 years of professional experience in comparison with users. We took into account the number of data points to ensure the tests were applicable in the entire study.

\section{Survey Instrument}

Table 2 presents the literature on which we based the questions of our survey. Table 2 does not present the literature for RQ1, which corresponds with survey question 1 , since it has already been discussed in Section 2.1.

Table 2. Survey's items and literature.

\begin{tabular}{|c|c|c|}
\hline & Survey's Items & Literature \\
\hline \multicolumn{3}{|c|}{ RQ2: Content of audit reports to enhance their value for decision making } \\
\hline \multicolumn{3}{|c|}{ Survey question 2: Information on the audit carried out (Category 1) } \\
\hline 1 & Level of assurance granted by the auditors & $\begin{array}{l}\text { CFA Institute (2010), Church et al. (2008), Gray et al. (2011), } \\
\text { Mock et al. (2013), Turner et al. (2010) }\end{array}$ \\
\hline 2 & $\begin{array}{l}\text { Detailed explanation of the scope and objective of the } \\
\text { audit and the engagement received }\end{array}$ & Church et al. (2008), Hatherly et al. (1991) \\
\hline 3 & Process carried out to audit the engagement & CFA Institute (2010), Mock et al. (2013), Porter et al. (2009) \\
\hline 4 & Audit risk assessment & $\begin{array}{l}\text { CFA Institute (2010), Church et al. (2008), Knechel et al. (2007), } \\
\text { MARC (2011), Porter et al. (2009) }\end{array}$ \\
\hline 5 & Source of the main errors detected during the audit & Church et al. (2008) \\
\hline 6 & Criteria used to determine materiality & $\begin{array}{l}\text { CFA Institute (2010), Coram et al. (2011), Gray et al. (2011), } \\
\text { Manson and Zaman (2001), Mock et al. (2013), Turner et al. } \\
\text { (2010) }\end{array}$ \\
\hline 7 & Auditor's responsibility towards third parties & Church et al. (2008), IAASB (2011a) \\
\hline 8 & Auditor's responsibility with regard to fraud & $\begin{array}{c}\text { CFA Institute (2010), Gray et al. (2011), Hatherly et al. (1991), } \\
\text { IAASB (2011a), Porter et al. (2009) }\end{array}$ \\
\hline 9 & $\begin{array}{l}\text { Auditor's responsibility regarding financial information } \\
\text { included in other company documentation (other than } \\
\text { annual accounts) }\end{array}$ & IAASB (2011a, 2011b), Porter et al. (2009) \\
\hline 10 & $\begin{array}{l}\text { Conclusions about the estimates and judgements made by } \\
\text { management in annual accounts }\end{array}$ & CFA Institute (2011), IAASB (2011a), Porter et al. (2009) \\
\hline \multicolumn{3}{|c|}{ Survey question 3: Information on the audit team and engagement statistics (Category 2) } \\
\hline 11 & Auditing experience of the engagement partner & Carey and Simnett (2006), CFA Institute (2010), MARC (2011) \\
\hline 12 & Industry experience of the engagement partner & Balsam et al. (2003), CFA Institute (2010) \\
\hline 13 & $\begin{array}{l}\text { Audit team composition and time spent on the audit by } \\
\text { each category }\end{array}$ & CFA Institute (2010), O’Keefe et al. (1994) \\
\hline 14 & $\begin{array}{l}\text { Experts' involvement and time spent on each area of } \\
\text { the audit }\end{array}$ & Johnstone and Bédard (2001), Knechel et al. (2007) \\
\hline 15 & $\begin{array}{l}\text { Other services provided by the auditor and procedures to } \\
\text { ensure the auditor's independence }\end{array}$ & $\begin{array}{l}\text { CFA Institute (2010), Hatherly et al. (1991), IAASB (2011a), } \\
\text { Porter et al. (2009), Turner et al. (2010) }\end{array}$ \\
\hline 16 & $\begin{array}{l}\text { Importance of the client for the audit firm in percentage } \\
\text { of revenues }\end{array}$ & CFA Institute (2010), Reynolds and Francis (2001) \\
\hline
\end{tabular}


Table 2. Cont.

\begin{tabular}{|c|c|c|}
\hline & Survey's Items & Literature \\
\hline \multicolumn{3}{|c|}{ Survey question 4: Information on annual accounts and on client's information systems (Category 3) } \\
\hline 17 & Assessment of the quality of internal control systems & $\begin{array}{l}\text { CFA Institute (2010), Church et al. (2008), Gray et al. (2011), } \\
\text { IAASB (2011a), Porter et al. (2009) }\end{array}$ \\
\hline 18 & $\begin{array}{l}\text { Assessment of the appropriateness of the client's } \\
\text { accounting policies and practices }\end{array}$ & $\begin{array}{c}\text { CFA Institute (2011), Church et al. (2008), IAASB (2011a), } \\
\text { Porter et al. (2009), Turner et al. (2010) }\end{array}$ \\
\hline 19 & $\begin{array}{l}\text { Information on communications with those charged } \\
\text { with governance }\end{array}$ & $\begin{array}{l}\text { CFA Institute (2010), Church et al. (2008), EC (2010), IAASB } \\
\text { (2011a), IOSCO (2009), Turner et al. (2010) }\end{array}$ \\
\hline 20 & $\begin{array}{l}\text { Percentage of waived and adjusted misstatements in } \\
\text { annual accounts }\end{array}$ & Church et al. (2008), Porter et al. (2009), Turner et al. (2010) \\
\hline 21 & $\begin{array}{l}\text { Procedures implemented by the company to prevent } \\
\text { fraud or illegal acts }\end{array}$ & Carcello (2012) \\
\hline 22 & Assessment of the sustainability of the client's business & CFA Institute (2011), IAASB (2011a), Turner et al. (2010) \\
\hline 23 & $\begin{array}{l}\text { Relevant information disclosed in management letter and } \\
\text { not included in annual accounts }\end{array}$ & $\begin{array}{l}\text { CFA Institute (2011), Gray et al. (2011), IOSCO (2009), Knechel } \\
\text { et al. (2007) }\end{array}$ \\
\hline 24 & $\begin{array}{l}\text { Assessment of the quality of the client's } \\
\text { forward-looking information }\end{array}$ & $\begin{array}{l}\text { EC (2010), IAASB (2011a), Porter et al. (2009), Turner et al. } \\
\text { (2010) }\end{array}$ \\
\hline 25 & $\begin{array}{l}\text { Comments on unusual transactions, reformulations and } \\
\text { other significant changes that occurred during the } \\
\text { audited period }\end{array}$ & Carcello (2012) \\
\hline 26 & $\begin{array}{l}\text { Comments on the sensitivity tests carried out by the } \\
\text { auditors in the most significant areas in which judgements } \\
\text { and estimates are used }\end{array}$ & Carcello (2012) \\
\hline \multicolumn{3}{|c|}{ RQ3: Format of audit reports to enhance their value for decision making-Survey question 5} \\
\hline 1 & $\begin{array}{l}\text { One-sentence audit report about the fairness and quality } \\
\text { of the audited financial statements }\end{array}$ & $\begin{array}{l}\text { Church et al. (2008), Gray et al. (2011), McEnroe and Martens } \\
\text { (2001) }\end{array}$ \\
\hline 2 & $\begin{array}{l}\text { One-sentence audit report containing a score on the } \\
\text { fairness and quality of the financial statements }\end{array}$ & EC (2010), Gray et al. (2011) \\
\hline 3 & $\begin{array}{l}\text { Actual audit report supplemented with expanded use of } \\
\text { emphases of matters paragraphs (information items } \\
\text { proposed previously) }\end{array}$ & $\begin{array}{c}\text { Gray et al. (2011), Hatherly et al. (1991), IAASB (2011a), } \\
\text { Turner et al. (2010) }\end{array}$ \\
\hline 4 & $\begin{array}{l}\text { Actual audit report supplemented with a discussion and } \\
\text { analysis report that includes all or some of the information } \\
\text { items proposed previously }\end{array}$ & Church et al. (2008), Hatherly et al. (1998), Turner et al. (2010) \\
\hline 5 & Free-form long audit report & Church et al. (2008), Hatherly et al. (1998), Turner et al. (2010) \\
\hline
\end{tabular}

Based on this literature on audit reports, we developed and administered an online survey related to audit reports' value for decision making and possible ways to improve these reports. In doing so, we distinguish between the content and the format of audit reports, as seen in MARC (2011).

An earlier version of the survey instrument was reviewed by five practicing auditors, all at high professional levels (partner, manager, and senior) and by five users who were experts on financial topics. They were asked to evaluate the questionnaire based on aspects such as clarity or ambiguity in the exposition of the issues as well as relevance to the field of study. They were also asked to make comments regarding the capacity to contextualize the instructions, the time for completing the questionnaire and the sequence of the questions. Survey pre-tests are often used to solve problems before surveys go into the field (Dillman et al. 2014; Przychodzen et al. 2016). Based on the feedback received, the final questionnaire was improved and administered online to survey participants. The 212 valid questionnaires were completed from April to October 2016. 
The questionnaire began by collecting individual data on the respondents, as reported in Table 1. It contained five questions for all participants. The questions are detailed in Table 3.

Table 3. Survey questions.

\begin{tabular}{cccc}
\hline Research Questions & $\begin{array}{c}\text { Question } \\
\text { Number }\end{array}$ & Questions & Possible Answers \\
\hline $\begin{array}{c}\text { RQ1: What decision-making } \\
\text { value do stakeholders attribute to } \\
\text { audit reports? }\end{array}$ & 1 & $\begin{array}{c}\text { Assess the decision-making value granted by investors and } \\
\text { other stakeholders to audit reports report in force in April } \\
\text { 2016 in Spain. }\end{array}$ & $\begin{array}{c}\text { Five-point Likert scale with 1 } \\
\text { equaling 'no value' and 5 } \\
\text { indicating 'much value' }\end{array}$ \\
\hline
\end{tabular}

Would the inclusion of following information on the audit carried out (Category 1 ) add value for decision making to the audit report in force in April 2016 in Spain? Level of assurance granted by the auditors; Detailed explanation of the scope and objective of the audit and the engagementreceived; Process carried out to audit the engagement; Audit risk assessment; Source of the main errors detected during the audit; Criteria used to determine materiality; Auditor's responsibility towards third parties; Auditor's responsibility with regard to fraud; Auditor's responsibility regarding financial information included in other company documentation (other than annual accounts); Conclusions about the estimates and judgements made by management in annual accounts.

Five-point Likert scale with 1 equaling 'it does not add any value' and 5 indicating 'it adds much value
$\mathrm{RQ2}$ : What content should audit reports contain in order to enhance their value for decision making?
Would the inclusion of following information on the audit team and engagement's statistics (Category 2 ) add value for decision making to the audit report in force in April 2016 in Spain? Auditing experience of the engagement partner; Industry experience of the engagement partner; Audit team composition and time spent on the audit by each category; Experts' involvement and time spent on each area of the audit; Other services provided by the auditor and procedures to ensure the auditor's independence; Importance of the client for the audit firm (in percentage of revenues).
Would the inclusion of following information on annual accounts and on client's information systems (Category 3 ) add value for decision making to the audit report in force

in April 2016 in Spain? Assessment of the quality of internal control systems; Assessment of the appropriateness of the client's accounting policies and practices; Information on communications with those charged with governance; Percentage of waived and adjusted misstatements in annual account; Procedures implemented by the company to prevent fraud or illegal acts; Assessment of the sustainability of the client's business; Relevant information disclosed in management letter and not included in annual accounts; Assessment of the quality of the client's forward-looking information; Comments on unusual transactions, reformulations and other significant changes that occurred during the audited period; Comments on the sensitivity tests carried out by

the auditors in the most significant areas in which judgements and estimates are used.
Five-point Likert scale with 1 equaling 'it does not add any value' and 5 indicating 'it adds much value
Five-point Likert scale with 1 equaling 'it does not add any value' and 5 indicating 'it adds much value'
RQ3: What format should audit reports have in order to enhance their value for decision making?
Asses the value for decision making added by following formats to the audit report in force in April 2016 in Spain: One-sentence audit report about the fairness and quality of the audited financial statements; One-sentence audit report containing a score on the fairness and quality of the financial statements; Actual audit report supplemented with expanded use of emphases of matters paragraphs (information items proposed previously); Actual audit report supplemented with a discussion and analysis report that includes all or some of the information items proposed
Five-point Likert scale with 1 equaling 'it does not add any value' and 5 indicating 'it adds much value' 
The five questions referred to audit reports in force in Spain in April 2016, when the questionnaire was launched. For this reason, the audit report in force at that point of time (ICAC 2013) was made available to respondents. The information items to which the survey questions refer were not included in the audit reports in force in Spain in April 2016. Audit reports in Spain were modified by NIA-ES 700 and NIA-ES 701 (ICAC 2016a, 2016b) (as we described previously), effective for audits of financial statements for periods beginning on or after 17 June 2016. Our respondents were aware that the new legislation would introduce changes to audit reports but were not familiar with these changes. No audit reports had been issued in Spain under the new legislation, when the questionnaires were completed. Our study compares the results of the survey with the novelties introduced by the legislation and proposes an alternative audit reporting model. Questions 2, 3 and 4 were related to modifications of the content of audit reports to add value for decision making. Based on the information categories described previously by MARC (2011) and other audit report literature, we presented participants 26 information items that could be included in audit reports to improve their value for decision making. These items were grouped in the following information categories: category 1 was related to information on the audit carried out, category 2 was related to information on the audit team and engagement statistics, and category 3 was related to information on the annual accounts and the client's information systems. We reduced the first four information categories of MARC (2011) to three; we did not extend the scope of our study to non-financial information. We have no doubt about the importance of this information (Miralles-Quirós et al. 2017), but the issue of its assurance has already been discussed in Gómez-Bezares and Goicoechea (2013) and Goicoechea et al. (2019).

Question 5 was related to the format of audit reports to add value for decision making. Five possible formats were proposed to the survey participants.

\section{Discussion of Results}

In this section, we present and discuss the survey results for RQ1, RQ2, and RQ3. All survey questions were rated on an ordinal scale from one to five, unless we indicate otherwise. Mean tests are not appropriate when data are skewed (Pallant 2013) or when ordinal data are used (Nunnally and Berstein 1994). In all cases, the means and medians were directionally consistent. We performed parametric tests corresponding to the nonparametric tests shown and obtained very similar results.

\subsection{RQ1: The Value of Audit Reports for Decision Making}

Table 4 presents our findings regarding respondents' perceptions of the decisionmaking value granted by stakeholders to audit reports. We assessed the mean responses of our two groups (users and auditors). Respondents considered that stakeholders grant high value to audit reports in terms of decision making. The means were above the central value (3) in each group. The Wilcoxon $\mathrm{W}$ test showed that the medians were significantly higher than three in each group. These results are encouraging because prior literature has shown the importance of audit reports for stakeholders (Chen and Church 1996; Church et al. 2008; Duréndez Gómez-Guillamón 2003; Firth 1980; Vanstraelen et al. 2012), as we outline above. These results also indicate that there is still room for improvement in audit reports value, as previous studies have also shown (Bartlett and Chandler 1999; Coram et al. 2011; Gray et al. 2011; Turner et al. 2010; Vanstraelen et al. 2012; Vergoossen 1993; Wright and Robbie 1996). We used the Mann-Whitney $U$ test to compare users and auditors and, we did not find a significant difference in their perceptions $(p=0.310)$. Next, we examine respondents' perceptions of the content of audit reports to enhance their value for decision making under RQ2. 
Table 4. Perceptions of the value granted by stakeholders to audit reports.

\begin{tabular}{ccccccc}
\hline Survey Item $^{\mathbf{b}}$ & \multicolumn{3}{c}{ Users } & \multicolumn{3}{c}{ Auditors } \\
\cline { 2 - 7 } & Mean & $\mathbf{W}^{\mathbf{a}}$ & $\boldsymbol{p}$ & Mean & $\mathbf{W}^{\mathbf{a}}$ & $\boldsymbol{p}$ \\
\hline $\begin{array}{c}\text { Decision-making value granted by investors } \\
\text { and other stakeholders to audit reports }\end{array}$ & 3.80 & 6.788 & 0.000 & 3.92 & 7.588 & 0.000 \\
\hline
\end{tabular}

Notes: ${ }^{a}$ We used the Wilcoxon $W$ test to compare users' $(n=109)$ and auditors' $(n=103)$ medians with the expected value of 3. All $p$-values were two-tailed, and we considered $p$-values equal to or less than 0.05 as significant. ${ }^{b}$ Participants rated this item on a scale from 1 (no value) to 5 (much value).

\subsection{RQ2: Content of Audit Reports to Enhance Their Value for Decision Making}

Table 5 summarizes the findings regarding respondents' perceptions of the content of audit reports to increase their value for decision making. We assessed the mean responses of our two groups (users and auditors). Users considered that all proposed information items would add value to audit reports. We determined that respondents believed an item would provide value if they scored it three or more. Users' means were all above the central value (3) for the 26 items in the three categories. Auditors, on the other hand, considered that all information items from category 1 (information on the audit carried out) and category 3 (information on annual accounts and on the client's information systems), except 'process carried out to audit the engagement', would add value to audit reports. Auditors' means were all above the central value (3) for all items of these categories except for the aforementioned item $($ mean $=2.97)$. Auditors considered that none of the information items from category 2 (information on the audit team and engagement statistics) would add value to audit reports except 'other services provided by the auditor and procedures to ensure the auditor's independence'. Auditors' means were all under the central value (3) for all information items of category 2 except for the aforementioned item (mean $=3.14)$. The reason for the low values could be that the publication of information on the audit team and engagement statistics may weaken its position against competitors and, in general, could be attributed to the desire not to disclose certain information.

Table 5. Perceptions of the content of audit reports to enhance their value.

\begin{tabular}{|c|c|c|c|c|c|c|c|}
\hline \multirow{2}{*}{ Survey Items ${ }^{b}$} & \multicolumn{3}{|c|}{ Users } & \multicolumn{3}{|c|}{ Auditors } & \multirow{2}{*}{$\begin{array}{c}\text { Selected } \\
\text { Items }\end{array}$} \\
\hline & Mean & $\mathbf{W}^{\mathbf{a}}$ & $p$ & Mean & $\mathbf{W}^{\mathbf{a}}$ & $p$ & \\
\hline Level of assurance granted by the auditors & 4.28 & 8.716 & 0.000 & 3.73 & 5.001 & 0.000 & Yes \\
\hline $\begin{array}{l}\text { Detailed explanation of the scope and objective of the audit } \\
\text { and the engagement received }\end{array}$ & 4.12 & 7.765 & 0.000 & 3.85 & 5.696 & 0.000 & Yes \\
\hline Process carried out to audit the engagement & 3.69 & 6.163 & 0.000 & 2.97 & -0.280 & 0.780 & \\
\hline Audit risk assessment & 4.44 & 8.557 & 0.000 & 3.40 & 2.814 & 0.005 & Yes \\
\hline Source of the main errors detected during the audit & 4.33 & 8.465 & 0.000 & 4.02 & 6.496 & 0.000 & Yes \\
\hline Criteria used to determine materiality & 3.97 & 7.383 & 0.000 & 3.17 & 1.356 & 0.175 & \\
\hline Auditor's responsibility towards third parties & 3.98 & 6.912 & 0.000 & 3.91 & 6.398 & 0.000 & Yes \\
\hline Auditor's responsibility with regard to fraud & 4.11 & 7.655 & 0.000 & 4.03 & 6.911 & 0.000 & Yes \\
\hline $\begin{array}{l}\text { Auditor's responsibility regarding financial information } \\
\text { included in other company documentation (other than } \\
\text { annual accounts) }\end{array}$ & 3.86 & 6.397 & 0.000 & 3.64 & 4.562 & 0.000 & Yes \\
\hline $\begin{array}{l}\text { Conclusions about the estimates and judgements made by } \\
\text { management in annual accounts }\end{array}$ & 4.35 & 8.549 & 0.000 & 4.17 & 7.287 & 0.000 & Yes \\
\hline
\end{tabular}


Table 5. Cont.

\begin{tabular}{|c|c|c|c|c|c|c|c|}
\hline \multirow{2}{*}{ Survey Items ${ }^{b}$} & \multicolumn{3}{|c|}{ Users } & \multicolumn{3}{|c|}{ Auditors } & \multirow{2}{*}{$\begin{array}{l}\text { Selected } \\
\text { Items }\end{array}$} \\
\hline & Mean & $\mathbf{W}^{\mathbf{a}}$ & $p$ & Mean & $\mathbf{W}^{\mathbf{a}}$ & $p$ & \\
\hline Total category 1: Information on the audit carried out & 4.11 & 8.992 & 0.000 & 3.68 & 6.918 & 0.000 & \\
\hline Auditing experience of the engagement partner & 3.28 & 2.051 & 0.040 & 2.56 & -3.822 & 0.000 & \\
\hline Industry experience of the engagement partner & 3.44 & 3.143 & 0.002 & 2.83 & -1.596 & 0.111 & \\
\hline $\begin{array}{l}\text { Audit team composition and time spent on the audit by } \\
\text { each category }\end{array}$ & 3.15 & 1.106 & 0.269 & 2.36 & -5.015 & 0.000 & \\
\hline $\begin{array}{l}\text { Experts' involvement and time spent on each area of } \\
\text { the audit }\end{array}$ & 3.47 & 3.658 & 0.000 & 2.73 & -2.398 & 0.016 & \\
\hline $\begin{array}{l}\text { Other services provided by the auditor and procedures to } \\
\text { ensure the auditor's independence }\end{array}$ & 4.14 & 7.904 & 0.000 & 3.14 & 0.679 & 0.503 & \\
\hline $\begin{array}{l}\text { Importance of the client for the audit firm in percentage } \\
\text { of revenues }\end{array}$ & 3.82 & 6.132 & 0.000 & 2.58 & -3.257 & 0.001 & \\
\hline $\begin{array}{c}\text { Total category 2: Information on the audit team and } \\
\text { engagement statistics }\end{array}$ & 3.55 & 5.536 & 0.000 & 2.70 & -2.440 & 0.015 & \\
\hline Assessment of the quality of internal control systems & 4.40 & 8.920 & 0.000 & 3.98 & 6.542 & 0.000 & Yes \\
\hline $\begin{array}{l}\text { Assessment of the appropriateness of the client's } \\
\text { accounting policies and practices }\end{array}$ & 4.40 & 8.961 & 0.000 & 3.87 & 6.122 & 0.000 & Yes \\
\hline $\begin{array}{l}\text { Information on communications with those charged } \\
\text { with governance }\end{array}$ & 4.00 & 7.694 & 0.000 & 3.52 & 3.697 & 0.000 & Yes \\
\hline $\begin{array}{l}\text { Percentage of waived and adjusted misstatements in } \\
\text { annual accounts }\end{array}$ & 3.84 & 6.108 & 0.000 & 3.56 & 3.809 & 0.000 & Yes \\
\hline $\begin{array}{l}\text { Procedures implemented by the company to prevent fraud } \\
\text { or illegal acts }\end{array}$ & 4.40 & 8.918 & 0.000 & 3.90 & 5.850 & 0.000 & Yes \\
\hline Assessment of the sustainability of the client's business & 4.08 & 7.268 & 0.000 & 3.49 & 3.500 & 0.000 & Yes \\
\hline $\begin{array}{l}\text { Relevant information disclosed in management letter and } \\
\text { not included in annual accounts }\end{array}$ & 3.94 & 6.668 & 0.000 & 3.29 & 2.050 & 0.040 & Yes \\
\hline $\begin{array}{l}\text { Assessment of the quality of the client's } \\
\text { forward-looking information }\end{array}$ & 3.87 & 7.116 & 0.000 & 3.41 & 2.678 & 0.007 & Yes \\
\hline $\begin{array}{c}\text { Comments on unusual transactions, reformulations and } \\
\text { other significant changes that occurred during the } \\
\text { audited period }\end{array}$ & 4.17 & 8.145 & 0.000 & 3.93 & 6.124 & 0.000 & Yes \\
\hline $\begin{array}{l}\text { Comments on the sensitivity tests carried out by the } \\
\text { auditors in the most significant areas in which judgements } \\
\text { and estimates are used }\end{array}$ & 4.10 & 7.727 & 0.000 & 3.63 & 4.015 & 0.000 & Yes \\
\hline $\begin{array}{c}\text { Total category 3: Information on the annual accounts and } \\
\text { on the client's information systems }\end{array}$ & 4.12 & 8.976 & 0.000 & 3.67 & 5.945 & 0.000 & \\
\hline Total all information items & 3.98 & 9.001 & 0.000 & 3.45 & 5.787 & 0.000 & \\
\hline
\end{tabular}

Notes: a We used the Wilcoxon $W$ test to compare users' $(n=109)$ and auditors' $(n=103)$ medians with the expected value of 3 . All $p$-values were two-tailed, and we considered $p$-values equal to or less than 0.05 as significant. ${ }^{\mathrm{b}}$ Participants rated these items on a scale from 1 (it does not add any value) to 5 (it adds much value).

Comparing users to auditors, we found one notable difference. Users attached higher value to all of the proposed information items; users' means were above auditors' means for all information items. In future studies, it would be interesting to examine whether the reason for the higher value attached by users than by auditors lies in the fact that users' answers could be given without cost considerations or other reasons. It would also be interesting to study whether the lower value given by auditors was a consequence of the 
increase in auditors' perceptions of litigation risks associated with the new disclosures (Gimbar et al. 2016; In et al. 2020).

We used the Mann-Whitney $U$ test to compare users and auditors and found significant differences between their perceptions except for on the following items: detailed explanation of the scope and objective of the audit and the engagement received $(p=0.096)$, auditor's responsibility towards third parties $(p=0.464)$, auditor's responsibility with regard to fraud $(p=0.422)$, auditor's responsibility regarding financial information included in other company documentation $(p=0.223)$, conclusions about estimates and judgements $(p=0.385)$, percentage of waived and adjusted misstatements in annual accounts $(p=0.109)$, comments on unusual transactions, reformulations and other significant changes $(p=0.341)$, and comments on sensitivity tests $(p=0.087)$.

As our objective is to propose an alternative audit report model to the current one, as per ISA 700, we should include the information items on which auditors and users agreed regarding the value added. Therefore, we should select items whose medians significantly exceeded the central value (3) in both groups. We include the 18 selected information items in Table 5.

We believe that it would not be appropriate to include so many information items in audit reports since the reports would probably become too long and difficult to use and therefore not read. Thus, we select the items that our respondents preferred, that is, those considered to contribute more in relative terms to the value of audit reports. With this goal in mind, we have centered each answer of each respondent by subtracting to the value granted by each individual to each item of information its own mean of the total of proposed items. These new values, therefore, indicate the relative estimation of each respondent of the relative value added by each information item compared to the value added by all items. These values allow us to analyse the preferences of our respondents.

Table 6 presents our findings for respondents' preferences regarding the content of audit reports. We assessed the mean responses of our two groups (users and auditors). To propose an alternative audit report, we selected items whose medians positively and significantly exceeded the central value (0) in both groups, as those items were preferred by users as well as by auditors. Table 6 shows the eight selected information items. Since they were preferred by both groups, we did not increase the gaps. Some of these items were already identified by MARC (2011) and Vanstraelen et al. (2012) in their interviews with auditors and audit report users.

Table 6. Preferences regarding the content of audit report to enhance its value.

\begin{tabular}{|c|c|c|c|c|c|c|c|}
\hline \multirow{2}{*}{ Survey Items ${ }^{b}$} & \multicolumn{3}{|c|}{ Users } & \multicolumn{3}{|c|}{ Auditors } & \multirow{2}{*}{$\begin{array}{l}\text { Selected } \\
\text { Items }\end{array}$} \\
\hline & Mean & $\mathrm{W}^{\mathrm{a}}$ & $p$ & Mean & $W^{a}$ & $p$ & \\
\hline Level of assurance granted by the auditors & 0.30 & 4.433 & 0.000 & 0.26 & 3.046 & 0.002 & Yes \\
\hline $\begin{array}{l}\text { Detailed explanation of the scope and objective of the } \\
\text { audit and the engagement received }\end{array}$ & 0.13 & 1.849 & 0.064 & 0.38 & 4.313 & 0.000 & \\
\hline Process carried out to audit the engagement & -0.30 & -3.744 & 0.000 & -0.47 & -3.914 & 0.000 & \\
\hline Audit risk assessment & 0.45 & 6.144 & 0.000 & -0.05 & 0.181 & 0.857 & \\
\hline Source of the main errors detected during the audit & 0.35 & 4.700 & 0.000 & 0.57 & 6.196 & 0.000 & Yes \\
\hline Criteria used to determine materiality & -0.01 & 0.406 & 0.685 & -0.28 & -2.907 & 0.004 & \\
\hline Auditor's responsibility towards third parties & 0.00 & 0.697 & 0.486 & 0.47 & 4.185 & 0.000 & \\
\hline Auditor's responsibility with regard to fraud & 0.13 & 2.318 & 0.020 & 0.58 & 5.412 & 0.000 & Yes \\
\hline $\begin{array}{l}\text { Auditor's responsibility regarding financial information } \\
\text { included in other company documentation (other than } \\
\text { annual accounts) }\end{array}$ & -0.12 & -0.990 & 0.322 & 0.20 & 1.787 & 0.074 & \\
\hline $\begin{array}{l}\text { Conclusions about the estimates and judgements made } \\
\text { by management in annual accounts }\end{array}$ & 0.36 & 5.247 & 0.000 & 0.70 & 7.237 & 0.000 & Yes \\
\hline
\end{tabular}


Table 6. Cont.

\begin{tabular}{|c|c|c|c|c|c|c|c|}
\hline \multirow{2}{*}{ Survey Items ${ }^{b}$} & \multicolumn{3}{|c|}{ Users } & \multicolumn{3}{|c|}{ Auditors } & \multirow{2}{*}{$\begin{array}{l}\text { Selected } \\
\text { Items }\end{array}$} \\
\hline & Mean & $\mathbf{W}^{\mathbf{a}}$ & $p$ & Mean & $\mathbf{W}^{\mathbf{a}}$ & $p$ & \\
\hline Total category 1: Information on the audit carried out & 0.13 & 4.531 & 0.000 & 0.23 & 5.266 & 0.000 & \\
\hline Auditing experience of the engagement partner & -0.70 & -6.011 & 0.000 & -0.88 & -7.384 & 0.000 & \\
\hline Industry experience of the engagement partner & -0.54 & -4.464 & 0.000 & -0.62 & -5.328 & 0.000 & \\
\hline $\begin{array}{l}\text { Audit team composition and time spent on the audit by } \\
\text { each category }\end{array}$ & -0.84 & -6.875 & 0.000 & -1.09 & -7.790 & 0.000 & \\
\hline $\begin{array}{l}\text { Experts' involvement and time spent on each area of } \\
\text { the audit }\end{array}$ & -0.52 & -5.003 & 0.000 & -0.72 & -5.995 & 0.000 & \\
\hline $\begin{array}{l}\text { Other services provided by the auditor and procedures } \\
\text { to ensure the auditor's independence }\end{array}$ & 0.15 & 2.354 & 0.019 & -0.31 & -2.610 & 0.009 & \\
\hline $\begin{array}{l}\text { Importance of the client for the audit firm in percentage } \\
\text { of revenues }\end{array}$ & -0.15 & -1.116 & 0.264 & -0.86 & -6.599 & 0.000 & \\
\hline $\begin{array}{c}\text { Total category 2: Information on the audit team and } \\
\text { engagement statistics }\end{array}$ & -0.43 & -6.491 & 0.000 & -0.75 & -8.229 & 0.000 & \\
\hline Assessment of the quality of internal control systems & 0.42 & 5.696 & 0.000 & 0.54 & 6.059 & 0.000 & Yes \\
\hline $\begin{array}{l}\text { Assessment of the appropriateness of the client's } \\
\text { accounting policies and practices }\end{array}$ & 0.41 & 5.592 & 0.000 & 0.42 & 6.276 & 0.000 & Yes \\
\hline $\begin{array}{l}\text { Information on communications with those charged } \\
\text { with governance }\end{array}$ & 0.01 & 0.297 & 0.767 & 0.08 & 1.130 & 0.190 & \\
\hline $\begin{array}{l}\text { Percentage of waived and adjusted misstatements in } \\
\text { annual accounts }\end{array}$ & -0.14 & -0.810 & 0.418 & 0.12 & 1.711 & 0.087 & \\
\hline $\begin{array}{l}\text { Procedures implemented by the company to prevent } \\
\text { fraud or illegal acts }\end{array}$ & 0.41 & 5.932 & 0.000 & 0.45 & 4.807 & 0.000 & Yes \\
\hline Assessment of the sustainability of the client's business & 0.10 & 1.853 & 0.064 & 0.05 & 1.072 & 0.284 & \\
\hline $\begin{array}{l}\text { Relevant information disclosed in management letter } \\
\text { and not included in annual accounts }\end{array}$ & -0.04 & 0.191 & 0.849 & -0.15 & -1.477 & 0.140 & \\
\hline $\begin{array}{l}\text { Assessment of the quality of the client's } \\
\text { forward-looking information }\end{array}$ & -0.12 & -1.712 & 0.087 & -0.02 & 0.385 & 0.700 & \\
\hline $\begin{array}{l}\text { Comments on unusual transactions, reformulations and } \\
\text { other significant changes that occurred during the } \\
\text { audited period }\end{array}$ & 0.17 & 2.793 & 0.005 & 0.49 & 5.108 & 0.000 & Yes \\
\hline $\begin{array}{c}\text { Comments on the sensitivity tests carried out by the } \\
\text { auditors in the most significant areas in which } \\
\text { judgements and estimates are used }\end{array}$ & 0.10 & 1.634 & 0.102 & 0.19 & 2.180 & 0.029 & \\
\hline $\begin{array}{l}\text { Total category 3: Information on the annual accounts } \\
\text { and on the client's information systems }\end{array}$ & 0.13 & 3.543 & 0.000 & 0.22 & 5.119 & 0.000 & \\
\hline
\end{tabular}

Notes: ${ }^{a}$ We used the Wilcoxon $W$ test to compare users' $(n=109)$ and auditors' $(n=103)$ medians with the expected value of 0 . All $p$-values were two-tailed, and we considered $p$-values equal to or less than 0.05 as significant. ${ }^{b}$ Participants rated these items on a scale from 1 (it does not add any value) to 5 (it adds much value), but subtracting the mean of each individual.

Once we selected the additional information to include in audit reports, we next examined respondents' perception of the format of audit reports under RQ3.

\subsection{RQ3: Format of Audit Reports to Enhance Their Value for Decision Making}

Table 7 presents our findings regarding respondents' perceptions of the format of audit reports to increase their value for decision making. We assessed the mean responses of our two groups (users and auditors). Users considered that all proposed formats (except the free-form long audit report) would add value to audit reports. Their means were all above the central value (3) for all proposed formats except the free-form long audit report. 
Auditors, on the other hand, considered that only the two formats more similar to the one in force (an actual report supplemented with an expanded use of emphasis of matter paragraphs and an actual report supplemented with a discussion and analysis report) would add value to audit reports. Their means were above the central value (3) only for the two mentioned formats. The mean for the non-standardized long format obtained in both groups is under the central value. Although the excessive standardization of audit reports is one of the problems described in the literature (Church et al. 2008; Mock et al. 2013), our results showed that a certain degree of standardization is desired by both users and auditors.

Table 7. Perceptions of format of audit reports to enhance their value.

\begin{tabular}{|c|c|c|c|c|c|c|c|}
\hline \multirow{2}{*}{ Survey Items ${ }^{b}$} & \multicolumn{3}{|c|}{ Users } & \multicolumn{3}{|c|}{ Auditors } & \multirow{2}{*}{$\begin{array}{l}\text { Selected } \\
\text { Items }\end{array}$} \\
\hline & Mean & $\mathbf{W}^{\mathbf{a}}$ & $p$ & Mean & $W^{a}$ & $p$ & \\
\hline $\begin{array}{c}\text { One-sentence audit report about the fairness and } \\
\text { quality of audited financial statements }\end{array}$ & 3.38 & 2.991 & 0.003 & 2.26 & -5.304 & 0.000 & \\
\hline $\begin{array}{l}\text { One-sentence audit report containing a score on the } \\
\text { fairness and quality of financial statements }\end{array}$ & 3.69 & 4.851 & 0.000 & 2.09 & -6.290 & 0.000 & \\
\hline $\begin{array}{l}\text { Actual audit report supplemented with expanded } \\
\text { use of emphases of matter paragraphs (information } \\
\text { items proposed previously) }\end{array}$ & 4.00 & 7.743 & 0.000 & 3.64 & 4.701 & 0.000 & Yes \\
\hline $\begin{array}{l}\text { Actual audit report supplemented with a discussion } \\
\text { and analysis report that includes all or some of the } \\
\text { information items proposed previously }\end{array}$ & 4.08 & 7.172 & 0.000 & 3.66 & 4.301 & 0.000 & Yes \\
\hline Free-form long audit report & 2.90 & -0.850 & 0.395 & 2.89 & -0.686 & 0.493 & \\
\hline
\end{tabular}

Notes: ${ }^{\text {a }}$ We used the Wilcoxon $W$ test to compare users' $(n=109)$ and auditors' $(n=103)$ medians with the expected value of 3 . All $p$-values were two-tailed, and we considered $p$-values equal to or less than 0.05 as significant. ${ }^{\mathrm{b}}$ Participants rated these items on a scale from 1 (it does not add any value) to 5 (it adds much value).

Comparing users to auditors, we found one notable difference. Users attached higher value to all proposed format items. This fact was already observed when analysing users' and auditors' perceptions of audit report content. As we noted above, it would be interesting for future studies to analyse the reasons for this fact. We used the Mann-Whitney $U$ test to compare users and auditors, and we found significant differences between their perceptions, except in relation to the free-form long format $(p=0.905)$.

To select the format that our respondents preferred, we performed the same procedures as we used with report content, centering each respondent's answer as described in the previous section for the information items. Table 8 summarizes the findings for respondents' preferences regarding the format of audit reports. We assessed the mean responses of our two groups (users and auditors). We selected those formats whose medians positively and significantly exceed the central value ( 0 ) in both groups. Table 8 shows the two selected formats. Because they are preferred by both groups, we do not increase the gaps.

We used the Wilcoxon Signed-Rank test to compare the perceptions of each group (users and auditors) regarding the two preferred formats, and we did not find significant differences between their preferences ( $\left.p_{\text {users }}=0.440 ; p_{\text {auditors }}=0.717\right)$. We observed a slight preference among users and auditors for the format 'Actual audit report supplemented with a discussion and an analysis report that includes all or some of the information items proposed previously'. The mean responses of our two groups were slightly higher for the aforementioned format than for the format 'Actual audit report supplemented with expanded use of emphases of matter paragraphs'. Nevertheless, we propose the format 'A ctual audit report supplemented with expanded use of emphases of matter paragraphs (information items proposed previously)' for the following reasons. We would place most of the information items previously selected in the 'Auditor's Responsibilities for the Audit of the Financial Statements' section. In our opinion, important information, the items preferred by our respondents, should be located within the body of the auditor's report. 
We believe that paragraphs located there are more likely to be read by users. The risk that readers do not read the 'Discussion and analysis report' is high, as previous studies demonstrate (Bédard and Gonthier-Besacier 2013). Our decision is consistent with ISA 700, as it states that the description of the auditor's responsibilities shall be included within the body of audit reports, within an appendix or in a reference to a website (IAASB 2015a).

Table 8. Preferences regarding the format of audit reports to enhance their value.

\begin{tabular}{|c|c|c|c|c|c|c|c|}
\hline \multirow{2}{*}{ Survey Items ${ }^{b}$} & \multicolumn{3}{|c|}{ Users } & \multicolumn{3}{|c|}{ Auditors } & \multirow{2}{*}{$\begin{array}{l}\text { Selected } \\
\text { Items }\end{array}$} \\
\hline & Mean & $\mathbf{W}^{\mathbf{a}}$ & $p$ & Mean & $\mathbf{W}^{\mathbf{a}}$ & $p$ & \\
\hline $\begin{array}{l}\text { One-sentence audit report about the fairness and quality } \\
\text { of audited financial statements }\end{array}$ & -0.24 & -2.436 & 0.015 & -0.65 & -5.419 & 0.000 & \\
\hline $\begin{array}{l}\text { One-sentence audit report containing a score on the } \\
\text { fairness and quality of financial statements }\end{array}$ & 0.08 & 1.143 & 0.253 & -0.82 & -7.031 & 0.000 & \\
\hline $\begin{array}{c}\text { Actual audit report supplemented with expanded use of } \\
\text { emphases of matter paragraphs (information items } \\
\text { proposed previously) }\end{array}$ & 0.38 & 4.675 & 0.000 & 0.73 & 5.891 & 0.000 & Yes \\
\hline $\begin{array}{l}\text { Actual audit report supplemented with a discussion and } \\
\text { analysis report that includes all or some of the } \\
\text { information items proposed previously }\end{array}$ & 0.48 & 4.845 & 0.000 & 0.75 & 6.103 & 0.000 & Yes \\
\hline Free-form long audit report & -0.70 & -5.548 & 0.000 & -0.02 & -0.071 & 0.943 & \\
\hline
\end{tabular}

Notes: ${ }^{\text {a }}$ We used the Wilcoxon $W$ test to compare users' $(n=109)$ and auditors' $(n=103)$ medians with the expected value of 0 . All $p$-values were two-tailed, and we considered $p$-values equal to or less than 0.05 as significant. ${ }^{\mathrm{b}}$ Participants rated these items on a scale from 1 (it does not add any value) to 5 (it adds much value), but subtracting the mean of each individual.

\section{Our Audit Report Proposal}

Based on the results of our survey, we conclude that auditors and financial report users do not want significant changes to the audit report format. Regarding report content, our respondents chose eight information items to be incorporated in audit reports to enhance their value for decision making. We next examine whether the eight information items are already taken into account in the revised ISA 700 (IAASB 2015a) and, if not, where to place them in audit reports.

The first identified item (Table 6) is 'Level of assurance granted by auditors'. ISA 700 states in paragraph 37 (a) and (b) that an audit report should include in the section 'Auditor's Responsibilities for the Audit of the Financial Statements' an explanation about the reasonable assurance obtained in the audit. Therefore, we think that this aspect is already covered by the new audit standard.

The second item is 'Source of the main errors detected during the audit'. ISA 700 does not issue requirements regarding this information. We believe that this item should be included in the 'Auditor's Responsibilities for the Audit of Financial Statements' section. As noted, the audit report literature has already remarked that stakeholders need more information about audit findings (Humphrey et al. 2009).

The third item is 'Auditor's responsibility with regard to fraud'. Although paragraph 38 (b) (i) of ISA 700 describes the auditor's responsibilities as 'to identify and assess the risks of material misstatement of the financial statements, whether due to fraud or error', we think that this information is insufficient. Stakeholders would benefit from an explicit and clear explanation of auditors' responsibility with regard to fraud, as this information would narrow the expectation gap (Akther and Xu 2020; Church et al. 2008; Porter 1993). The 'halo effect', or changes in users' perceptions about things not mentioned in audit reports, is especially significant regarding a company's lack of fraud in an unqualified audit report (Hatherly et al. 1991). We propose the inclusion of the following explanation: 'The audit work is not specifically intended to detect fraud of all types and amounts that may have been committed and, therefore, cannot be expected to be one of its results. However, 
if during the course of our work we had detected evidence or existence of fraud we are obliged to communicate it'.

The fourth item is 'Conclusions about the estimates and judgements made by management in annual accounts'. The description of the auditor's responsibilities includes, in paragraph 38 (b) (iii) of ISA 700, that they have 'to evaluate the reasonableness of accounting estimates and related disclosures made by management'. Nevertheless, we opine that the auditor's detailed conclusions about the main accounting estimates should be included in audit reports. Since accounting standards have moved from being rules based to being principles based, auditors' advise on interpretation and implementation of accounting standards is more necessary (Brown et al. 2014). There are many balance, and profit and loss captions that require important estimates from those who prepare financial statements. We principally consider assets' useful life, valuation, and impairment as well as provisions and contingencies.

The fifth item is 'Assessment of the quality of internal control systems'. ISA 700 specifically states in paragraph 38 (b) (ii) that it is not within auditors' responsibilities to express their opinion on the effectiveness of the entity's internal control. Such an auditor opinion about an 'integrated assurance', according to PCAOB Auditing Standard no. 2201 (PCAOB 2007) - 'An audit of internal control over financial reporting that is integrated with an audit of financial statements' - is required under Section 404 of the US Sarbanes-Oxley Act, but is not required in the EU. The opinion about internal control systems should be placed in the 'Auditor's Opinion' section of audit reports. The section regarding the responsibilities for financial statements should be renamed to 'Responsibilities of Management for Financial Statements and the Internal Control System' and should include the description of the responsibilities of management regarding the maintenance and assessment of effective internal control over financial reporting.

The sixth item is 'Assessment of the appropriateness of the client's accounting policies and practices'. The description of the auditor's responsibilities includes in ISA 700, paragraph 38 (b) (iii), that they have 'to evaluate the appropriateness of accounting policies'. Paragraph 38 (b) (iv) describes the auditor's responsibility to conclude about the use of the going concern basis of accounting. International Financial Reporting Standards (IFRS) are becoming more complex. In particular, the latest IFRS issued, IFRS 9 'Financial Instruments', IFRS 15 'Revenue from Contracts with clients', IFRS 16 'Leases' and IFRS 17 'Insurance Contracts', imply a high degree of interpretation from financial statement preparers. We believe that detailed information about the auditor's assessment regarding the main accounting policies, not only regarding going concern, would benefit stakeholders and should be included in audit reports (Aljinovic Barac et al. 2017).

The seventh item is 'Procedures implemented by the company to prevent fraud or illegal acts'. Such information is not considered by audit reports, as of ISA 700. Taking into account that the description of the procedures can be extensive, we believe that a specific reference link to the annual accounts or the website of the entity should be included in the audit report section 'Responsibilities of Management for Financial Statements'.

The last item chosen is 'Comments on unusual transactions, reformulations and other significant changes that occurred during the audited period'. As this information is not considered by ISA 700, we believe that it should be included in the 'Auditor's Responsibilities for the Audit of Financial Statements' section of the audit report.

Given the current structure of an audit report as per ISA 700, and based on the perceptions of our survey respondents, we propose an audit report model with following additional information. We describe only the sections in which we have proposed additional information.

(1) Auditor's Opinion. This section would include the auditor's opinion on the effectiveness of the system of internal control after the opinion on the financial statements is presented.

(2) Responsibilities of Management for Financial Statements and the Internal Control System. This section would include the following additional information: a specific refer- 
ence link to the annual accounts or website of the entity, where the procedures implemented by the company to prevent fraud or illegal acts are detailed, and the responsibilities of the entity regarding the maintenance of effective internal control over financial reporting and the assessment of the effectiveness of internal control over financial reporting.

(3) Auditor's Responsibilities for the Audit of Financial Statements. This section should include the following additional information: a description of the source of the main errors detected during the audit; an explicit description of the auditor's responsibilities with regard to fraud; the auditor's conclusions about the estimates and judgements made by management in annual accounts; an assessment of the appropriateness of the client's accounting policies and practices; and the auditor's comments on unusual transactions, reformulations and other significant changes that occurred during the audited period.

In our opinion, the above proposed audit report improves the usefulness of this report for decision making. It may substantially reduce the gaps, as it is based on the consensus between users and auditors. The proposed audit report also promotes audit quality, since it moves away from standardized formulations and focuses on client- and engagement-specific information.

\section{Conclusions, Limitations and Suggestions for Future Research}

In this section, we conclude, discuss some limitations of this study, and outline some suggestions for future research. Our study provides valuable insights regarding the decision-making value granted by stakeholders to audit reports and stakeholders' preferences regarding report format and content. Participants' responses generally support the notion that audit reports have important value for stakeholders, but there is still room for improvement. Although the latest regulatory changes increase the content of audit reports, auditors and users agree that more information should be given on certain matters related to audits and annual accounts as well as the client's information systems. Therefore, steps should be taken by regulators to incorporate this information into audit reports in order to narrow the expectation, information and communication gaps (Akther and $\mathrm{Xu}$ 2020) and to enhance the transparency on the quality of an audit. Our study also identifies differences and similarities in users' and auditors' perceptions of audit report preferences.

The quality of our participants' responses could have been influenced by the fact that the participants had different degrees of familiarity with audit activity. We tried to mitigate this problem with the pre-test of the survey instrument when problems with the understanding of certain questions were detected. We did not consider this a real problem because our intention was to analyse our respondents' perceptions and not the validity or authority of those perceptions (Corzo et al. 2012). Users' answers could be given without considering the associated costs (Humphrey et al. 1993; Mock et al. 2013). We tried to mitigate this problem by finding a consensus with the opinions of auditors who were well aware of cost factors. Auditors' answers, on the other hand, could be given considering that an extended audit report may lead to an increase in audit fees (Gutierrez et al. 2018). We believe that in addition to knowing these limitations, it is important that regulators and auditing standards setters know the specific information that users and auditors wish to be included in audit reports in order to evaluate future changes to reports. The presence of non-response bias was not analysed (Lambert and Harrington 1990). Nevertheless, our response rates were very high (near 90\%).

The study was conducted in a Spanish setting. While limiting the study to a single jurisdiction is an inherent limitation, there is European harmonization regarding audit legislation. The Big 4, which have been established in the Spanish audit market for decades, audited 100\% of IBEX 35 (main index of the Spanish stock market) listed companies in 2018. In 2010, Spain was the country with the largest percentage of companies obtaining assurance opinions for their sustainability reports (Eccles et al. 2012). This shows that Spanish companies and audit firms are well aware of the latest developments in the audit activity. Spanish auditors and financial report users are, in light of all these factors, in a strong position to provide detailed insights on audit report value and the possibilities 
to improve it. On the other hand, limiting the study to a jurisdiction allows greater homogeneity and consistency in the samples.

We did not study the relevance of non-financial information and the auditor's role in assuring such information for the benefit of the users. We have already indicated previously that this issue has been discussed in Gómez-Bezares and Goicoechea (2013) and Goicoechea et al. (2019). Nevertheless, given the growing importance of non-financial information and its assurance, we have no doubt that the assurance of this type of information is going to be subject to further research and will affect the structure of the audit report.

Despite the study's limitations, the results should be relevant for both academics and practitioners interested in enhancing the value of audit reports and narrowing the gaps between auditors and users. Our results provide insights into audit reports' value for decision making by stakeholders and improving possibilities. We identified eight information items as well as the format that would increase audit reports' value, in our participants' opinions. Because we sought a consensus between auditors and users, we did not increase the expectation, information and communication gaps; rather, we narrowed them. However, we recognize that it is not easy to close them completely (Coram and Wang 2020). The proposed audit report should satisfy the demands expressed by users without exceeding the possibilities for auditors. Therefore, we believe that our proposed report should be more successful than previous audit reports.

The results of this study should be of interest to regulators and auditor corporations that seek to enhance transparency on the quality of audit practice and regain confidence in this activity. We hope that our study will motivate the discussion of additional disclosures to improve audit reports, as these are the principal channel of communication between auditors and stakeholders.

An audit report faces the risk that it is so long, so dense or so complicated that it is not read. We tried to avoid that risk throughout the investigation. Frequently, respondents tend to see a lot of information as interesting, although it is not read later. That is why we selected only the most interesting information items; the need for consensus also reduced the number of information items to include in audit reports.

We also identified several topics that would most likely benefit from future research. There are two areas related to the incentive structure of the surveyed groups. First, respondents reported that they were not especially interested in audit reports including information on the audit team and engagement statistics. This finding is consistent with prior studies (MARC 2011; Vanstraelen et al. 2012). Future studies should analyse the reason for this lack of interest. Second, users valued all proposed information items and formats more than auditors. Users' perceptions could be formed without adequate cost considerations. Auditors' answers could be given considering the higher litigation risks associated with the new disclosures in audit reports or other ethical dilemmas (EspinosaPike and Barrainkua 2016). It would be interesting to analyse in future research the reasons for the higher values given by users than by auditors.

We also identify two issues that could be broadened in future research. First, a very interesting topic to study is the impact on audit fees and the cost and benefits of the proposed changes in audit reports (Bédard et al. 2016; Gray et al. 2011; Turner et al. 2010). Second, it would be very interesting to include non-professional investors in our study (Köhler et al. 2020). There might be significant differences between their perceptions regarding the issues addressed in the survey and the perceptions of the surveyed users.

Author Contributions: All authors contributed to each section of the article equally. All authors have read and agreed to the published version of the manuscript.

Funding: This paper was financially supported by Fundación Jesús de Gangoiti Barrera, Fundación Luis Bernaola and Deiker of the University of Deusto.

Data Availability Statement: The data that support the findings of this study are available from the corresponding author upon reasonable request. 
Acknowledgments: The authors thank the survey respondents who participated in this study. They appreciate feedback from the reviewers on early drafts of the survey instrument. The authors thank Fundación Jesús de Gangoiti Barrera, Fundación Luis Bernaola and Deiker of the University of Deusto for financial support. The authors also thank reviewers and editors for their helpful comments and suggestions that greatly improved the quality of the article.

Conflicts of Interest: The authors declare no conflict of interest.

\section{References}

Akther, Taslima, and Fengju Xu. 2020. Existence of the Audit Expectation Gap and Its Impact on Stakeholders' Confidence: The Moderating Role of the Financial Reporting Council. International Journal of Financial Studies 8: 4. [CrossRef]

Aljinovic Barac, Zeljana, Tina Vuko, and Slavko Šodan. 2017. What can auditors tell us about accounting manipulations? Managerial Auditing Journal 32: 788-809. [CrossRef]

Balsam, Steven, Jagan Krishnan, and Joon S. Yang. 2003. Auditor industry specialization and earnings quality. Auditing: A Journal of Practice E Theory 22: 71-97. [CrossRef]

Bartlett, Susan A., and Roy A. Chandler. 1999. The private shareholder, corporate governance and the role of the annual report. Journal of Business Law 1999: 415-28.

Bédard, Jean, and Nathalie Gonthier-Besacier. 2013. Le paragraphe de justification des appréciations dans le rapport des commissaires aux comptes. Partie 2: Contenu et lisibilité-Théorie et pratique. Revue Française de Comptabilité 471: 2-6.

Bédard, Jean, Nathalie Gonthier-Besacier, and Alain Schatt. 2014. Costs and benefits of reporting Key Audit Matters in the Audit Report: The French Experience. Available online: https://www.isarhq.org/2014_downloads/papers/ISAR2014_Bedard_Besacier_Schatt. pdf (accessed on 29 March 2021).

Bédard, Jean, Paul Coram, Reza Espahbodi, and Theodore J. Mock. 2016. Does recent academic research support changes to audit reporting standards? Accounting Horizons 30: 255-75. [CrossRef]

Boolaky, Pran K., and Reiner Quick. 2016. Bank Directors' Perceptions of Expanded Auditor's Reports. International Journal of Auditing 20: 158-74. [CrossRef]

Brasel, Kelsey, Marcus M. Doxey, Jonathan H. Grenier, and Andrew Reffett. 2016. Risk disclosure preceding negative outcomes: The effects of reporting critical audit matters on judgments of auditor liability. The Accounting Review 91: 1345-62. [CrossRef]

Brown, Philip, John Preiato, and Ann Tarca. 2014. Measuring country differences in enforcement of accounting standards: An audit and enforcement proxy. Journal of Business Finance \& Accounting 41: 1-52. [CrossRef]

Carcello, Joseph V. 2012. What do investors want from the standard audit report? Results of a survey of investors conducted by the PCAOB's investor advisory group. The CPA Journal 82: 22-28. Available online: https://search.proquest.com/docview/92340466 6? (accessed on 29 March 2021).

Carey, Peter, and Roger Simnett. 2006. Audit partner tenure and audit quality. The Accounting Review 81: 653-76. [CrossRef]

Caso, Covadonga, Julita García, Antonio López, and Antonio Martínez. 2003. Estudio de la incidencia de ciertos factores en el informe de auditoría. Spanish Accounting Review 6: 57-86.

CFA Institute. 2010. Independent Auditor's Report Survey Results. Available online: http://www.cfainstitute.org/Survey/ independent_auditors_report_survey_results.pdf (accessed on 29 November 2018). This link was no longer available by the end of this study. Therefore, we mentioned it always accompanied by other studies that refer to the same information.

CFA Institute. 2011. Usefulness of Independent Auditor's Report. Available online: https://www.cfainstitute.org/survey/usefulness_ of_independent_auditors_report_survey_results_march_2011.pdf (accessed on 29 March 2021).

Chen, Kevin C. W., and Bryan K. Church. 1996. Going concern opinions and the market's reaction to bankruptcy filings. The Accounting Review 71: 117-28.

Chen, Shimin, Bingbing Hu, Donghui Wu, and Ziye Zhao. 2020. When Auditors Say 'No,'Does the Market Listen? European Accounting Review 29: 263-305. [CrossRef]

Cheng, Mandy, Wendy Green, Pieter Conradie, Noriyuki Konishi, and Andrea Romi. 2014. The international integrated reporting framework: Key issues and future research opportunities. Journal of International Financial Management E Accounting 25: 90-119. [CrossRef]

Christensen, Brant E., Steven M. Glover, and Christopher J. Wolfe. 2014. Do critical audit matter paragraphs in the audit report change nonprofessional investors' decision to invest? Auditing: A Journal of Practice \& Theory 33: 71-93. [CrossRef]

Church, Bryan K., Shawn M. Davis, and Susan A. McCracken. 2008. The auditor's reporting model: A literature overview and research synthesis. Accounting Horizons 22: 69-90. [CrossRef]

Coffee, John C. 2019. Why do auditors fail? What might work? What won't? Accounting and Business Research 49: 540-61. [CrossRef]

Coram, Paul J., and Leiyu Wang. 2020. The Effect of Disclosing Key Audit Matters and Accounting Standard Precision on the Audit Expectation Gap. International Journal of Auditing, 1-13. [CrossRef]

Coram, Paul J., Theodore J. Mock, Jerry L. Turner, and Glen L. Gray. 2011. The communicative value of the auditor's report. Australian Accounting Review 21: 235-52. [CrossRef]

Corzo, Teresa, Margarita Prat, and Esther Vaquero. 2012. Behavioral Finance in Joseph de la Vega's Confusion de Confusiones. Journal of Behavioral Finance 15: 341-50. [CrossRef] 
De Villiers, Charl, Leonardo Rinaldi, and Jeffrey Unerman. 2014. Integrated reporting: Insights, gaps and an agenda for future research. Accounting, Auditing \& Accountability Journal 27: 1042-67. [CrossRef]

Deloitte. 2015. Annual Report Insights 2015. Building a Better Report. Available online: https:/ /www2.deloitte.com/content/dam/ Deloitte/uk/Documents/audit/deloitte-uk-annual-report-insights-2015-highlights.pdf (accessed on 29 March 2021).

Dillman, Don A., Jolene D. Smyth, and Leah M. Christian. 2014. Internet, Phone, Mail, and Mixed-Mode Surveys: The Tailored Design Method, 4th ed. Hoboken: JohnWiley \& Sons, Inc., ISBN 978-1-118-45614-9.

Duréndez Gómez-Guillamón, Antonio. 2003. The usefulness of the audit report in investment and financing decisions. Managerial Auditing Journal 18: 549-59. [CrossRef]

Eccles, Robert G., Michael P. Krzus, and Liv A. Watson. 2012. Integrated Reporting Requires Integrated Assurance. In Effective Auditing for Corporates: Key Developments in Practice and Procedures. London: Bloomsbury Information Ltd., pp. 161-78.

Epstein, Marc J., and Marshall A. Geiger. 1994. Investor views of audit assurance: Recent evidence of the expectation gap. Journal of Accountancy 177: 60-66.

Espinosa-Pike, Marcela, and Itsaso Barrainkua. 2016. An exploratory study of the pressures and ethical dilemmas in the audit conflict. Spanish Accounting Review 19: 10-20. [CrossRef]

European Commission (EC). 2010. Green Paper-Audit Policy: Lessons from the Crisis. Available online: https:/ /www.europarl.europa. eu/meetdocs/2009_2014/documents/com/com_com(2010)0561_/com_com(2010)0561_en.pdf (accessed on 29 March 2021).

European Parliament. 2014a. Directive 2014/56/EU of the European Parliament and of the Council of 16 April 2014 Amending Directive 2006/43/EC on Statutory Audits of Annual Accounts and Consolidated Accounts. Available online: https:/ / eur-lex. europa.eu/legal-content/EN/TXT/?uri=celex\%3A32014L0056 (accessed on 29 March 2021).

European Parliament. 2014b. Regulation (EU) No 537/2014 of the European Parliament and of the Council of 16 April 2014 on Specific Requirements Regarding Statutory Audit of Public-Interest Entities and Repealing Commission Decision 2005/909/EC. 2014. Available online: https:/ / eur-lex.europa.eu/legal-content/en/TXT/?uri=CELEX\%3A32014R0537 (accessed on 29 March 2021).

Financial Reporting Council (FRC). 2013. International Standard on Auditing (UK and Ireland) 700. The Independent Auditor's Report on Financial Statements. Available online: https://www.frc.org.uk/getattachment/501de004-b616-43c3-8d65-aeaebde19f8d/ ISA-700-(UK-and-Ireland)-700-(Revised)-Independent-auditors-report-June-2013.pdf (accessed on 29 March 2021).

Firth, Michael. 1980. A note on the impact of audit qualifications on lending and credit decisions. Journal of Banking \& Finance 4: 257-67. [CrossRef]

Gaeremynck, Ann, and Marleen Willekens. 2003. The endogenous relationship between audit-report type and business termination: Evidence on private firms in a non-litigious environment. Accounting and Business Research 33: 65-79. [CrossRef]

Garcia-Benau, M. Antonia, Christopher Humphrey, Peter Moizer, and Stuart Turley. 1993. Auditing expectations and performance in Spain and Britain: A comparative analysis. The International Journal of Accounting 28: 281-307.

Ghicas, Dimitrios C., Afroditi Papadaki, Georgia Siougle, and Theodore Sougiannis. 2008. The relevance of quantifiable audit qualifications in the valuation of IPOs. Review of Accounting Studies 13: 512-50. [CrossRef]

Gimbar, Christine, Bowe Hansen, and Michael E. Ozlanski. 2016. The effects of critical audit matter paragraphs and accounting standard precision on auditor liability. The Accounting Review 91: 1629-46. [CrossRef]

Goicoechea, Estibaliz, Fernando Gómez-Bezares, and José Vicente Ugarte. 2019. Integrated Reporting Assurance: Perceptions of Auditors and Users in Spain. Sustainability 11: 713. [CrossRef]

Gold, Anna, Melina Heilmann, Christiane Pott, and Johanna Rematzki. 2020. Do key audit matters impact financial reporting behavior? International Journal of Auditing 24: 232-44. [CrossRef]

Gómez-Bezares, Fernando, and Estibaliz Goicoechea. 2013. El futuro modelo de información corporativa. ¿Deben opinar los auditores sobre el informe integrado? Revista Visión Contable 11: 229-64. [CrossRef]

Gray, Glen L., Jerry L. Turner, Paul J. Coram, and Theodore J. Mock. 2011. Perceptions and misperceptions regarding the unqualified auditor's report by financial statement preparers, users, and auditors. Accounting Horizons 25: 659-84. [CrossRef]

Gutierrez, Elizabeth, Miguel Minutti-Meza, Kay W. Tatum, and Maria Vulcheva. 2018. Consequences of adopting an expanded auditor's report in the United Kingdom. Review of Accounting Studies 23: 1543-87. [CrossRef]

Hatherly, David, John Innes, and Tom Brown. 1991. The expanded audit report-An empirical investigation. Accounting and Business Research 21: 311-19. [CrossRef]

Hatherly, David, Tom Brown, and John Innes. 1998. Free-form reporting and perceptions of the audit. The British Accounting Review 30: 23-38. [CrossRef]

Horton, Joanne, Maria Tsipouridou, and Anthony Wood. 2018. European market reaction to audit reforms. European Accounting Review 27: 991-1023. [CrossRef]

Humphrey, Christopher, Anne Loft, and Margaret Woods. 2009. The global audit profession and the international financial architecture: Understanding regulatory relationships at a time of financial crisis. Accounting, Organizations and Society 34: 810-25. [CrossRef]

Humphrey, Christopher, Peter Moizer, and Stuart Turley. 1992. The audit expectations gap-Plus ça change, plus c'est la même chose? Critical Perspectives on Accounting 3: 137-61. [CrossRef]

Humphrey, Christopher, Peter Moizer, and Stuart Turley. 1993. The audit expectations gap in Britain: An empirical investigation. Accounting and Business Research 23: 395-411. [CrossRef]

Ianniello, Giuseppe, and Giuseppe Galloppo. 2015. Stock market reaction to auditor opinions-Italian evidence. Managerial Auditing Journal 30: 610-32. [CrossRef] 
In, Chang-yeol, Taeheung Kim, and Sambock Park. 2020. Key Audit Matters for Production-To-Order Industry and Conservatism. International Journal of Financial Studies 8: 5. [CrossRef]

Instituto de Contabilidad y Auditoría de Cuentas (ICAC). 2013. Norma Internacional de Auditoría (NIA-ES) 700. Formación de la Opinión y Emisión del Informe de Auditoría sobre los Estados Financieros. Available online: http://www.icac.gob.es (accessed on 29 March 2021).

Instituto de Contabilidad y Auditoría de Cuentas (ICAC). 2016a. Norma Internacional de Auditoría (NIA-ES) 700 (revisada). Formación de la Opinión y Emisión del Informe de Auditoría sobre los Estados Financieros. Available online: http://www.icac.gob.es (accessed on 29 March 2021).

Instituto de Contabilidad y Auditoría de Cuentas (ICAC). 2016b. Norma Internacional de Auditoría (NIA-ES) 701. Cuestiones Claves de Auditoría. Available online: http:/ / www.icac.gob.es (accessed on 29 March 2021).

International Auditing and Assurance Standards Board (IAASB). 2011a. Enhancing the Value of Auditor Reporting: Exploring Options for Change. Consultation Paper. Available online: https:/ / www.iaasb.org/publications/enhancing-value-auditor-reportingexploring-options-change-1 (accessed on 29 March 2021).

International Auditing and Assurance Standards Board (IAASB). 2011b. The Evolving Nature of Financial Reporting: Disclosure and Its Audit Implications. Discussion Paper. Available online: https://www.iaasb.org/publications/evolving-nature-financialreporting-disclosure-and-its-audit-implications (accessed on 29 March 2021).

International Auditing and Assurance Standards Board (IAASB). 2012. Invitation to Comment: Improving the Auditor's Report. Available online: https:/ / www.ifac.org/system/files/publications/files/Auditor\%20Reporting\%20At\%20a\%20Glance\%20June\% 202012\%20-\%20final.pdf (accessed on 29 March 2021).

International Auditing and Assurance Standards Board (IAASB). 2015a. Forming an Opinion and Reporting on Financial Statements. International Standard on Auditing (ISA) 700 (Revised). Available online: https://www.iaasb.org/publications/internationalstandard-auditing-isa-700-revised-forming-opinion-and-reporting-financial-statements-5 (accessed on 29 March 2021).

International Auditing and Assurance Standards Board (IAASB). 2015b. Communications Key Audit Matters in the Independent Auditor's Report. International Standard on Auditing (ISA) 701 (New). Available online: https://www.iaasb.org/publications/internationalstandard-auditing-isa-701-new-communicating-key-audit-matters-independent-auditors-4 (accessed on 29 March 2021).

International Integrated Reporting Council (IIRC). 2013. International <IR> Framework. Available online: http:/ /integratedreporting. org/resource/international-ir-framework/ (accessed on 29 March 2021).

International Integrated Reporting Council (IIRC). 2014. Assurance on <IR>: An Exploration of Issues. Available online: http:/ /integratedreporting.org/wp-content/uploads/2014/07/Assurance-on-IR-an-explorationof-issues.pdf (accessed on 29 March 2021).

International Organization of Securities Commissions (IOSCO) Technical Committee. 2009. Auditor Communications Consultation Report. Available online: https: / / www.iosco.org/library/pubdocs/pdf/IOSCOPD303.pdf (accessed on 29 March 2021).

Johnstone, Karla M., and Jean Bédard. 2001. Engagement planning, bid pricing, and client response in the market for initial attest engagements. The Accounting Review 76: 199-220. [CrossRef]

Kausar, Asad, and Clive Lennox. 2017. Balance sheet conservatism and audit reporting conservatism. Journal of Business Finance $\mathcal{E}$ Accounting 44: 897-924.

Knechel, W. Robert, Steven E. Salterio, and Brian Ballou. 2007. Auditing: Assurance and Risk, 3rd ed. Mason: Thomson South-Western, ISBN 978-1138692794.

Köhler, Annette, Nicole Ratzinger-Sakel, and Jochen Theis. 2020. The effects of key audit matters on the auditor's report's communicative value: Experimental evidence from investment professionals and non-professional investors. Accounting in Europe 17: 105-28. [CrossRef]

Kolk, Ans, and Rob Van Tulder. 2010. International business, corporate social responsibility and sustainable development. International Business Review 19: 119-25. [CrossRef]

KPMG. 2014. Audit Committees' and Auditors' Reports. A Short Survey of the New Reporting. Available online: https://home.kpmg/ content/dam/kpmg/ie/pdf/2016/10/ie-aci-survey-of-audit-committees-and-auditors-reports.pdf (accessed on 29 March 2021).

KPMG. 2017. The Road Ahead. The KPMG Survey of Corporate Responsibility Reporting 2017. Available online: https://assets. kpmg.com/content/dam/kpmg/xx/pdf/2017/10/kpmg-survey-of-corporate-responsibility-reporting-2017.pdf (accessed on 29 March 2021).

Lambert, Douglas M., and Thomas. C. Harrington. 1990. Measuring nonresponse bias in customer service mail surveys. Journal of Business Logistics 112: 5-25.

Maastricht Accounting Auditing and Information Management Research Center (MARC). 2011. A Framework for Extended Audit Reporting. Available online: https://www.accaglobal.com/content/dam/acca/global/PDF-technical/audit-publications/ extended_audit_reporting.pdf (accessed on 29 March 2021).

Manes-Rossi, Francesca, Adriana Tiron-Tudor, Giuseppe Nicolò, and Gianluca Zanellato. 2018. Ensuring More Sustainable Reporting in Europe Using Non-Financial Disclosure-De Facto and De Jure Evidence. Sustainability 10: 1162. [CrossRef]

Manigart, Sophie, Mike Wright, Ken Robbie, Philippe Desbrieres, and Koen De Waele. 1997. Venture capitalists' appraisal of investment projects: An empirical European study. Entrepreneurship Theory and Practice 21: 29-43. [CrossRef]

Manson, Stuart, and Mahbub Zaman. 2001. Auditor communication in an evolving environment: Going beyond SAS 600 auditors' reports on financial statements. The British Accounting Review 33: 113-36. [CrossRef] 
Mao, Mike Q., and Yangxin Yu. 2015. Analysts' cash flow forecasts, audit effort, and audit opinions on internal control. Journal of Business Finance \& Accounting 42: 635-64. [CrossRef]

McDonough, Ryan, Argyro Panaretou, and Catherine Shakespeare. 2020. Fair Value Accounting: Current Practice and Perspectives for Future Research. Journal of Business Finance \& Accounting 47: 303-32. [CrossRef]

McEnroe, John E., and Stanley C. Martens. 2001. Auditors' and investors' perceptions of the 'expectation gap'. Accounting Horizons 15: 345-58. [CrossRef]

Miralles-Quirós, M. del Mar, José L. Miralles-Quirós, M. Isabel Sánchez-Hernández, and Irene Guia Arraiano. 2017. Sustainability reporting in Europe: Differences in terms of legislation and valuation. R-LEGO: Revista Lusófona de Economia e Gestão das Organizações 26: 1014-28. Available online: https:/ / core.ac.uk/download/pdf/153419413.pdf (accessed on 29 March 2021).

Mock, Theodore J., Jean Bédard, Paul J. Coram, Shawn M. Davis, Reza Espahbodi, and Rick C. Warne. 2013. The audit reporting model: Current research synthesis and implications. Auditing: A Journal of Practice $\mathcal{E}$ Theory 32: 323-51. [CrossRef]

Moroney, Robyn, Soon-Yeow Phang, and Xinning Xiao. 2020. When Do Investors Value Key Audit Matters? European Accounting Review, 1-20. [CrossRef]

Muñoz-Izquierdo, Nora, M. del Mar Camacho-Miñano, M. Jesús Segovia-Vargas, and David Pascual-Ezama. 2019. Is the External Audit Report Useful for Bankruptcy Prediction? Evidence Using Artificial Intelligence. International Journal of Financial Studies 7: 20. [CrossRef]

Nunnally, Jum C., and Ira H. Berstein. 1994. Psycometric Theory. New York: McGraw Hill Series.

O'Keefe, Terrence B., Dan A. Simunic, and Michael T. Stein. 1994. The production of audit services: Evidence from a major public accounting firm. Journal of Accounting Research 32: 241-61. [CrossRef]

O'Reilly, Dennis. 2010. Do investors perceive the going-concern opinion as useful for pricing stocks? Managerial Auditing Journal 25: 4-16. [CrossRef]

Pallant, Julie. 2013. SPSS Survival Manual. New York: McGraw-Hill Education, ISBN 9780335262588.

Porter, Brenda. 1993. An empirical study of the audit expectation-performance gap. Accounting and Business Research 24: 49-68. [CrossRef]

Porter, Brenda, Ciaran Ó hÓgartaigh, and Rachel Baskerville. 2009. Report on Research Conducted in the United Kingdom and New Zealand in 2008 Investigating the Audit Expectation Performance Gap and User's Understanding of, and Desired Improvements to the Auditor's Report Research. Commissioned by the IAASB. Available online: https://www.ifac.org/system/files/downloads / Porter_et_al_Final_Report_Combined.pdf (accessed on 29 March 2021).

Przychodzen, Justyna, Fernando Gómez-Bezares, Wojciech Przychodzen, and Mikel Larreina. 2016. ESG Issues among fund managersFactors and motives. Sustainability 8: 1078. [CrossRef]

Public Company Accounting Oversight Board (PCAOB). 2007. AS 2201: An Audit of Internal Control over Financial Reporting That Is Integrated with an Audit of Financial Statements. Available online: https:/ / pcaobus.org:443/Standards / Auditing/Pages/AS220 1.aspx (accessed on 29 March 2021).

Public Company Accounting Oversight Board (PCAOB). 2011. Concept Release on Possible Revisions to PCAOB Standards Related to Reports on Audited Financial Statements. Available online: https://pcaobus.org/Rulemaking/Docket034/Concept_Release.pdf (accessed on 29 March 2021).

Public Company Accounting Oversight Board (PCAOB). 2017. AS 3101: The Auditor's Report on an Audit of Financial Statements When the Auditor Expresses an Unqualified Opinion. Available online: https://pcaobus.org/Standards/Auditing/Pages/AS3101.aspx (accessed on 29 March 2021).

PwC. 2014. Plain Speaking! Benchmarking the New Auditor's Report among Dutch Listed Entities. Available online: https: //www.pwc.nl/nl/assets/documents/pwc-benchmark-auditors-reporting.pdf (accessed on 29 March 2021).

Reynolds, J. Kenneth, and Jere R. Francis. 2001. Does size matter? The influence of large clients on office-level auditor reporting decisions. Journal of Accounting and Economics 30: 375-400. [CrossRef]

Rossi, Adriana, and Lara Tarquinio. 2017. An analysis of sustainability report assurance statements. Managerial Auditing Journal 36: 578-602. [CrossRef]

Ruhnke, Klaus, and Martin Schmidt. 2014. The audit expectation gap: Existence, causes, and the impact of changes. Accounting and Business Research 44: 572-601. [CrossRef]

Simnett, Roger, and Anna Huggins. 2014. Enhancing the auditor's report: To what extent is there support for the IAASB's proposed changes? Accounting Horizons 28: 719-47. [CrossRef]

Simnett, Roger, and Anna Huggins. 2015. Integrated reporting and assurance: Where can research add value? Sustainability Accounting, Management and Policy Journal 6: 29-53. [CrossRef]

Sirois, Louis P., Jean Bédard, and Palash Bera. 2018. The Informational Value of Key Audit Matters in the Auditor's Report: Evidence from an Eye-Tracking Study. Accounting Horizons 32: 141-62. [CrossRef]

Spanish Parliament. 2015. Audit Law 22/2015, of 20 July 2015. Available online: https:/ /www.boe.es/buscar/act.php?id=BOE-A-20 15-8147 (accessed on 29 March 2021).

Turner, Jerry L., Theodore J. Mock, Paul J. Coram, and Glen L. Gray. 2010. Improving transparency and relevance of auditor communications with financial statement users. Current Issues in Auditing 4: A1-A8. [CrossRef]

Vanstraelen, Ann, Caren Schelleman, Roger Meuwissen, and Isabell Hofmann. 2012. The audit reporting debate: Seemingly intractable problems and feasible solutions. European Accounting Review 21: 193-215. [CrossRef] 
Velte, Patrick, and Jakob Issa. 2019. The impact of Key Audit Matter (KAM) Disclosure in Audit Reports on Stakeholders' Reactions: A literature review. Problems and Perspectives in Management 17: 323-41. [CrossRef]

Vergoossen, Ruud G. A. 1993. The use and perceived importance of annual reports by investment analysts in the Netherlands. European Accounting Review 2: 219-44. [CrossRef]

Wright, Mike, and Ken Robbie. 1996. Venture capitalists, unquoted equity investment appraisal and the role of accounting information. Accounting and Business Research 26: 153-68. [CrossRef] 